\title{
Estimating Canopy Fuel Parameters for Atlantic Coastal Plain Forest Types
}

Report to the US Forest Service Savannah River - January, 2007

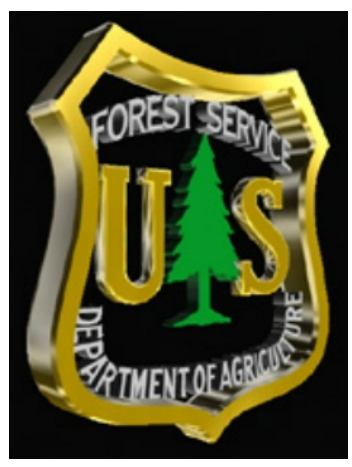

Bernard R. Parresol, Ph.D.

USDA Forest Service, Southern Research Station, Asheville, NC 28804

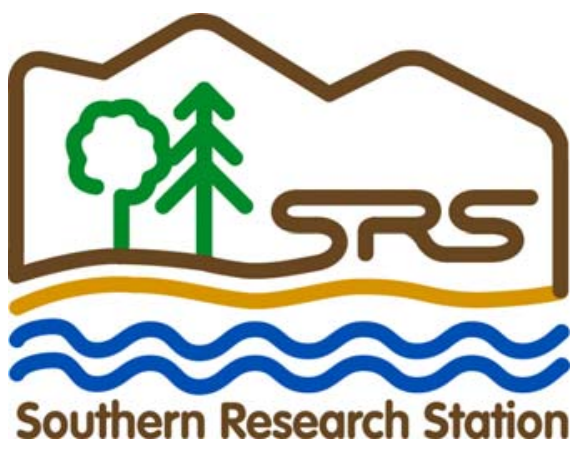




\section{Introduction}

It is necessary to quantify forest canopy characteristics to assess crown fire hazard, prioritize treatment areas, and design treatments to reduce crown fire potential. A number of fire behavior models such as FARSITE, FIRETEC, and NEXUS require as input four particular canopy fuel parameters: 1) canopy cover, 2) stand height, 3) crown base height, and 4) canopy bulk density. These canopy characteristics must be mapped across the landscape at high spatial resolution to accurately simulate crown fire. Currently no models exist to forecast these four canopy parameters for forests of the Atlantic Coastal Plain, a region that supports millions of acres of loblolly, longleaf, and slash pine forests as well as pine-broadleaf forests and mixed species broadleaf forests. Many forest cover types are recognized, too many to efficiently model. For expediency, forests of the Savannah River Site are categorized as belonging to 1 of 7 broad forest type groups, based on composition: 1) loblolly pine, 2) longleaf pine, 3) slash pine, 4) pine-hardwood, 5) hardwood-pine, 6) hardwoods, and 7) cypress-tupelo. These 7 broad forest types typify forests of the Atlantic Coastal Plain region, from Maryland to Florida.

Data to calculate the canopy characteristics and develop the models comes from an inventory of 622 plots, started in March 1999 and completed in January 2002. For each tree on a plot the following were recorded: diameter breast height in inches, total height in feet, height to base of live crown in feet, crown class, and species. From this data canopy cover (CC) expressed as a proportion, stand height $(\mathrm{SH})$ in feet, crown base height $(\mathrm{CBH})$ in feet, and canopy bulk density $(C B D)$ in $\mathrm{lb} / \mathrm{ft}^{3}$ were computed for each plot. Table 1 gives standard statistical measures on the canopy characteristics. The following information was recorded for each plot: stand age in years $(A)$, basal area in square feet per acre $(B A)$, site index in feet for base age $50(S I)$, number of burns for the plot $(N B)$, and years since last burn (YRS). Table 2 gives standard statistical measures on the plot variables. The Appendix lists the basic data used to develop the canopy models.

\section{Canopy Cover}

The canopy variable known as canopy cover $(C C)$ is the downward projection onto the ground of the horizontal tree canopies on a plot. To determine the horizontal area of the tree crowns I used a set of crown-diameter prediction models for the Eastern U.S. (Bechtold 2003). Because crowns can overlap, to avoid overestimating CC I used only the dominant and codominant trees. In reading the literature, the preferred way to measure $C C$ is to use an instrument like a densitometer (Jennings et al. 1999). Barring such data, some authors suggest using crown area of the dominant and codominants, arguing that crowns of intermediate and suppressed trees are almost always overlapped (McElhinny et al. 2005). Other authors suggest using the crown area of all trees and applying an adjustment factor that accounts for overlap (Crookston and Stage 1999). I opted for using the crown area of the dominant and codominant trees to create values of CC for each plot.

The next step was to model the plot values of $C C$ against the stand level variables of age $(A)$, basal area $(B A)$, site index $(S I)$, number of burns $(N B)$, and years since last burn (YRS). Because $C C$ ranges from 0 to 1 (or $0 \%$ to $100 \%$ ) it seemed appropriate to use the logistic function because it has asymptotes at 0 and 1 . The form of the general logistic function is: 
Table 1. Basic statistics describing the canopy characteristics for the 7 broad forest types.

\begin{tabular}{|c|c|c|c|c|c|c|c|}
\hline Forest Type & $\mathrm{N}$ & Characteristic & Median & Mean & STD & Min & Max \\
\hline Loblolly & 277 & $\begin{array}{l}C C \\
C B H(\mathrm{ft}) \\
S H(\mathrm{ft}) \\
C B D\left(\mathrm{lb} / \mathrm{ft}^{3}\right)\end{array}$ & $\begin{array}{l}0.792 \\
31.5 \\
69.6 \\
0.00350\end{array}$ & $\begin{array}{l}0.749 \\
31.7 \\
66.1 \\
0.00369\end{array}$ & $\begin{array}{l}0.215 \\
16.7 \\
24.3 \\
0.00173\end{array}$ & $\begin{array}{l}0.058 \\
1.0 \\
9.3 \\
0.00018\end{array}$ & $\begin{array}{l}0.999 \\
78.0 \\
120.7 \\
0.00878\end{array}$ \\
\hline Longleaf & 129 & $\begin{array}{l}C C \\
C B H(\mathrm{ft}) \\
S H(\mathrm{ft}) \\
C B D\left(\mathrm{lb} / \mathrm{ft}^{3}\right)\end{array}$ & $\begin{array}{l}0.628 \\
30.0 \\
68.6 \\
0.00243\end{array}$ & $\begin{array}{l}0.614 \\
27.7 \\
58.9 \\
0.00284\end{array}$ & $\begin{array}{l}0.218 \\
16.4 \\
24.7 \\
0.00168\end{array}$ & $\begin{array}{l}0.061 \\
0.0 \\
9.0 \\
0.00001\end{array}$ & $\begin{array}{l}0.992 \\
55.0 \\
93.0 \\
0.00769\end{array}$ \\
\hline Slash & 58 & $\begin{array}{l}C C \\
C B H(\mathrm{ft}) \\
S H(\mathrm{ft}) \\
C B D\left(\mathrm{lb} / \mathrm{ft}^{3}\right)\end{array}$ & $\begin{array}{l}0.580 \\
41.3 \\
82.4 \\
0.00376\end{array}$ & $\begin{array}{l}0.592 \\
37.6 \\
80.8 \\
0.00391\end{array}$ & $\begin{array}{l}0.184 \\
15.2 \\
12.1 \\
0.00168\end{array}$ & $\begin{array}{l}0.192 \\
3.0 \\
10.9 \\
0.00074\end{array}$ & $\begin{array}{l}0.981 \\
61.5 \\
97.3 \\
0.00767\end{array}$ \\
\hline Pine-Hardwood & 23 & $\begin{array}{l}C C \\
C B H(\mathrm{ft}) \\
S H(\mathrm{ft}) \\
C B D\left(\mathrm{lb} / \mathrm{ft}^{3}\right)\end{array}$ & $\begin{array}{l}0.596 \\
26.0 \\
72.6 \\
0.00235\end{array}$ & $\begin{array}{l}0.605 \\
24.2 \\
66.5 \\
0.00295\end{array}$ & $\begin{array}{l}0.187 \\
14.7 \\
26.9 \\
0.00179\end{array}$ & $\begin{array}{l}0.054 \\
3.0 \\
18.5 \\
0.00033\end{array}$ & $\begin{array}{l}0.938 \\
46.5 \\
112.5 \\
0.00657\end{array}$ \\
\hline Hardwood-Pine & 27 & $\begin{array}{l}C C \\
C B H(\mathrm{ft}) \\
S H(\mathrm{ft}) \\
C B D\left(\mathrm{lb} / \mathrm{ft}^{3}\right)\end{array}$ & $\begin{array}{l}0.721 \\
31.0 \\
84.0 \\
0.00335\end{array}$ & $\begin{array}{l}0.707 \\
31.2 \\
83.4 \\
0.00416\end{array}$ & $\begin{array}{l}0.205 \\
10.6 \\
12.6 \\
0.00388\end{array}$ & $\begin{array}{l}0.303 \\
16.0 \\
56.6 \\
0.00108\end{array}$ & $\begin{array}{l}0.992 \\
52.5 \\
111.8 \\
0.02152\end{array}$ \\
\hline Hardwoods & 103 & $\begin{array}{l}C C \\
C B H(\mathrm{ft}) \\
S H(\mathrm{ft}) \\
C B D\left(\mathrm{lb} / \mathrm{ft}^{3}\right)\end{array}$ & $\begin{array}{l}0.726 \\
27.0 \\
79.6 \\
0.00279\end{array}$ & $\begin{array}{l}0.718 \\
27.2 \\
76.6 \\
0.00340\end{array}$ & $\begin{array}{l}0.208 \\
12.4 \\
20.5 \\
0.00210\end{array}$ & $\begin{array}{l}0.207 \\
3.0 \\
28.3 \\
0.00022\end{array}$ & $\begin{array}{l}0.995 \\
54.0 \\
115.6 \\
0.01403\end{array}$ \\
\hline Cypress-Tupelo & 5 & $\begin{array}{l}C C \\
C B H(\mathrm{ft}) \\
S H(\mathrm{ft}) \\
C B D\left(\mathrm{lb} / \mathrm{ft}^{3}\right)\end{array}$ & $\begin{array}{l}0.879 \\
51.0 \\
100.3 \\
0.00479\end{array}$ & $\begin{array}{l}0.819 \\
53.0 \\
98.2 \\
0.00476\end{array}$ & $\begin{array}{l}0.171 \\
4.8 \\
6.7 \\
0.00021\end{array}$ & $\begin{array}{l}0.540 \\
49.0 \\
90.5 \\
0.00440\end{array}$ & $\begin{array}{l}0.970 \\
60.0 \\
105.7 \\
0.00495\end{array}$ \\
\hline
\end{tabular}

Note: STD is standard deviation, min is minimum value, max is maximum value. For the canopy characteristics, $C C$ is canopy cover, $C B H$ is crown base height, $S H$ is stand height, and $C B D$ is canopy bulk density. 
Table 2. Basic statistics describing the stands of the Savannah River Site by forest type.

\begin{tabular}{|c|c|c|c|c|c|c|c|}
\hline Forest Type & $\mathrm{N}$ & Variable & Median & Mean & STD & Min & Max \\
\hline \multirow[t]{5}{*}{ Loblolly } & \multirow[t]{5}{*}{277} & Age & 33.00 & 33.18 & 18.30 & 2.00 & 100.00 \\
\hline & & SI & 80.00 & 84.13 & 9.67 & 60.00 & 110.00 \\
\hline & & $B A$ & 106.54 & 107.63 & 39.41 & 0.98 & 218.46 \\
\hline & & $N B$ & 1.00 & 1.51 & 1.16 & 0.00 & 5.00 \\
\hline & & YRS & 7.00 & 13.21 & 12.14 & 0.50 & 33.00 \\
\hline \multirow[t]{5}{*}{ Longleaf } & \multirow[t]{5}{*}{129} & Age & 41.00 & 38.12 & 19.54 & 1.00 & 88.00 \\
\hline & & $S I$ & 80.00 & 75.89 & 10.28 & 50.00 & 100.00 \\
\hline & & $B A$ & 67.50 & 71.96 & 39.30 & 0.88 & 212.04 \\
\hline & & $N B$ & 2.00 & 1.98 & 1.09 & 0.00 & 5.00 \\
\hline & & YRS & 4.00 & 8.02 & 9.17 & 0.50 & 33.00 \\
\hline \multirow{5}{*}{ Slash } & \multirow{5}{*}{58} & Age & 44.00 & 43.93 & 7.04 & 4.00 & 62.00 \\
\hline & & $S I$ & 80.00 & 83.79 & 6.71 & 60.00 & 90.00 \\
\hline & & $B A$ & 100.67 & 104.81 & 34.71 & 7.39 & 178.75 \\
\hline & & $N B$ & 2.00 & 1.64 & 0.95 & 0.00 & 4.00 \\
\hline & & YRS & 6.50 & 10.10 & 9.59 & 0.50 & 33.00 \\
\hline \multirow[t]{5}{*}{ Pine-Hardwood } & \multirow[t]{5}{*}{23} & Age & 48.00 & 47.35 & 21.14 & 3.00 & 80.00 \\
\hline & & $S I$ & 80.00 & 77.61 & 14.76 & 40.00 & 110.00 \\
\hline & & $B A$ & 76.91 & 81.35 & 44.53 & 13.16 & 157.20 \\
\hline & & $N B$ & 1.00 & 1.48 & 1.24 & 0.00 & 4.00 \\
\hline & & YRS & 7.00 & 13.04 & 13.14 & 0.50 & 33.00 \\
\hline \multirow[t]{5}{*}{ Hardwood-Pine } & \multirow[t]{5}{*}{27} & Age & 56.00 & 54.37 & 13.66 & 21.00 & 88.00 \\
\hline & & $S I$ & 90.00 & 85.93 & 9.71 & 60.00 & 100.00 \\
\hline & & $B A$ & 112.65 & 116.14 & 31.97 & 38.05 & 180.00 \\
\hline & & $N B$ & 1.00 & 1.04 & 1.19 & 0.00 & 4.00 \\
\hline & & YRS & 14.00 & 18.50 & 13.73 & 0.50 & 33.00 \\
\hline \multirow{5}{*}{ Hardwoods } & \multirow[t]{5}{*}{103} & Age & 56.00 & 54.16 & 16.78 & 0.00 & 95.00 \\
\hline & & SI & 80.00 & 80.44 & 14.45 & 50.00 & 110.00 \\
\hline & & BA & 104.29 & 112.08 & 45.35 & 8.96 & 238.66 \\
\hline & & NB & 1.00 & 0.96 & 0.99 & 0.00 & 3.00 \\
\hline & & YRS & 19.00 & 18.65 & 13.14 & 0.50 & 33.00 \\
\hline \multirow[t]{3}{*}{ Cypress-Tupelo } & \multirow[t]{3}{*}{5} & Age & 80.00 & 108.40 & 52.58 & 75.00 & 199.00 \\
\hline & & SI & 90.00 & 86.00 & 18.17 & 60.00 & 110.00 \\
\hline & & BA & 313.75 & 299.75 & 40.22 & 234.61 & 337.50 \\
\hline
\end{tabular}

Note: STD is standard deviation, min and max are minimum and maximum, Age is in years, $S I$ is site index (ft) at 50 years, $B A$ is basal area $\left(\mathrm{ft}^{2}\right), N B$ is number burns, and $Y R S$ is years since burn. 


$$
\widehat{C C}=\left[1+e^{\mathbf{b x}}\right]^{-1}
$$

where the linear combinations for the independent variables can be given as

$$
\mathbf{b X}=b_{0}+b_{1} A+b_{2} B A+b_{3} S I+b_{4} N B+b_{5} Y R S
$$

In a few instances having exponents on the independent variables improved the fit, e.g., $A^{c_{1}}$ and $B A^{c_{2}}$. In no cases were there any significant interactions. Below are the equations for each of the 7 forest type groups. Non-significant coefficients/variables have been dropped.

Loblolly:

$$
\begin{aligned}
& \widehat{C C}=\left[1+\exp \left(4.41413 A^{0.18857}-3.49500 B A^{0.21977}\right]^{-1}\right. \\
& N=274 ; R^{2}=0.714 ; R M S E=0.1131
\end{aligned}
$$

Longleaf:

$$
\begin{aligned}
& \widehat{C C}=\left[1+\exp \left(4.09530 A^{0.17942}-5.22865 B A^{0.13916}+0.014636 S I\right]^{-1}\right. \\
& N=127 ; R^{2}=0.506 ; R M S E=0.1517
\end{aligned}
$$

Slash:

$$
\begin{aligned}
& \widehat{C C}=\left[1+\exp (1.65566-0.019317 B A]^{-1}\right. \\
& N=57 ; R^{2}=0.708 ; R M S E=0.0972
\end{aligned}
$$

Pine-Hardwood:

$$
\begin{aligned}
& \widehat{C C}=-0.2+\left[1+\exp \left(2.61273-4.358 \times 10^{-6} B A^{2.71196}-0.025872 S I-1.09297 N B\right]^{-1}\right. \\
& N=23 ; R^{2}=0.631 ; R M S E=0.1257
\end{aligned}
$$

Hardwood-Pine:

$$
\begin{aligned}
& \widehat{C C}=\left[1+\exp (2.49703+0.026827 A-0.020864 B A-0.028661 S I]^{-1}\right. \\
& N=26 ; R^{2}=0.615 ; R M S E=0.1334
\end{aligned}
$$

Hardwoods:

$$
\begin{aligned}
& \widehat{C C}=\left[1+\exp (0.30213+0.016226 A-0.020942 B A]^{-1}\right. \\
& N=97 ; R^{2}=0.470 ; R M S E=0.1439
\end{aligned}
$$

Cypress-Tupelo:

$$
\begin{aligned}
& \widehat{C C}=\left[1+\exp (3.8558-0.0668 S I]^{-1}\right. \\
& N=5 ; R^{2}=0.922 ; R M S E=0.0550
\end{aligned}
$$




\section{Crown Base Height and Stand Height}

The variable known as crown base height $(C B H)$ is generally defined as the average height to the bottom of the tree crowns in the stand (Keane et al. 2000). According to Scott and Reinhardt (2001), CBH is not well defined for a stand. They state that neither the lowest crown base height in a stand nor the average crown base height is likely to be representative of the stand as a whole, especially for multistory stands. Still, many researchers (e.g. Fulé et al. 2004) use height to base of live crown $(H B L C)$ per tree and take the average to determine $C B H$. Notwithstanding, I decided to use the median value of $H B L C$ to characterize $C B H$ for a plot. The median value is a more stable parameter than the mean as it is unaffected by extreme values. In looking closely at the data for the Savannah River Site, I observed that for some plots the mean was smaller then the median, and in other plots the reverse was true. What was most illuminating is that in trying to regress $C B H$ against the stand level values of $A, B A, S I, N B$, and $Y R S$, the coefficients of determination $\left(R^{2}\right)$ were almost doubled when using the median $H B L C$ values for $C B H$ as opposed to using the mean $H B L C$ values for $C B H$.

There is consensus for the variable known as stand height $(\mathrm{SH})$, being the average height of the dominant tree layer (Keane et al. 2000). Basically, I took a weighted average of the heights of the dominant and codominant trees on a plot.

The next step was to model the plot values of $C B H$ and $S H$ against the stand level variables of age $(A)$, basal area $(B A)$, site index $(S I)$, number of burns $(N B)$, and years since last burn $(Y R S)$. It is important to note that for stands that have not been burned, insert the value 33 for YRS. In general the data is nonlinear. It seemed expedient to use a standard growth function that is widely accepted in forestry, namely the Bertalanffy-Richards function (sometimes known as the Chapman-Richards function). This function has an upper asymptote that constrains the predictions so unreasonably high values will not occur, no matter the combination of input variables. Zero is a lower asymptote (no worries about negative values). The form of the Bertalanffy-Richards function is:

$$
\hat{Y}=a\left(1-\mathrm{e}^{\mathbf{b x}}\right)^{P}
$$

where $\hat{Y}$ is $C B H$ or $S H, a$ is the upper asymptote, $P$ is a power exponent, and the linear combinations for the independent variables can be given as

$$
\mathbf{b X}=b_{1} A+b_{2} B A+b_{3} S I+b_{4} N B+b_{5} Y R S
$$

Below are the equations for $C B H$ for each of the 7 forest type groups. Non-significant coefficients/variables have been dropped. Burn history had a small but noticeable effect on 4 of the forest type groups, all the pines and the hardwood-pine group. 
Loblolly:

$$
\begin{aligned}
& \widehat{C B H}=55.659(1-\exp (-0.038000 A-0.0045089 B A-0.021561 S I+0.0096688 Y R S))^{14.876} \\
& N=276 ; R^{2}=0.647 ; R M S E=10.0247
\end{aligned}
$$

Longleaf:

$$
\begin{aligned}
& \widehat{C B H}=49.516(1-\exp (-0.043809 A-0.0070967 B A-0.056397 S I+0.018079 Y R S))^{281.66} \\
& N=127 ; R^{2}=0.718 ; R M S E=8.9100
\end{aligned}
$$

Slash:

$$
\begin{aligned}
& \widehat{C B H}=48.702(1-\exp (-0.14817 A-0.030608 B A+0.065986 Y R S))^{1523.2} \\
& N=55 ; R^{2}=0.464 ; R M S E=10.8647
\end{aligned}
$$

Pine-Hardwood:

$$
\begin{aligned}
& \widehat{C B H}=49.289(1-\exp (-0.035551 A-0.039489 S I))^{73.938} \\
& N=23 ; R^{2}=0.823 ; R M S E=6.6434
\end{aligned}
$$

Hardwood-Pine:

$$
\begin{aligned}
& \widehat{C B H}=50.000(1-\exp (-0.00072979 A-0.044384 S I+0.017028 Y R S))^{23.503} \\
& N=26 ; R^{2}=0.474 ; R M S E=7.6557
\end{aligned}
$$

Hardwoods:

$$
\begin{aligned}
& \widehat{C B H}=50.000(1-\exp (-0.018566 A-0.0036229 B A-0.026947 S I))^{20.574} \\
& N=101 ; R^{2}=0.629 ; R M S E=7.6990
\end{aligned}
$$

Cypress-Tupelo:

$$
\begin{aligned}
& \widehat{C B H}=60.536(1-\exp (-0.028109 A-0.0084594 S I))^{3.7372} \\
& N=5 ; R^{2}=0.998 ; R M S E=0.4728
\end{aligned}
$$


Below are the equations for $\mathrm{SH}$ for each of the 7 forest type groups. Non-significant coefficients/variables have been dropped. Burn history had no effect on stand height.

Loblolly:

$$
\begin{aligned}
& \widehat{S H}=109.47(1-\exp (-0.036511 A-0.0027096 B A-0.015610 S I))^{7.0469} \\
& N=275 ; R^{2}=0.904 ; R M S E=7.5798
\end{aligned}
$$

Longleaf:

$$
\begin{aligned}
& \widehat{S H}=87.139(1-\exp (-0.048577 A-0.0081846 B A-0.037393 S I))^{56.834} \\
& N=127 ; R^{2}=0.872 ; R M S E=8.9683
\end{aligned}
$$

Slash:

$$
\begin{aligned}
& \widehat{S H}=90.313(1-\exp (-0.058330 A-0.0060502 B A-0.085693 S I))^{2433.9} \\
& N=57 ; R^{2}=0.899 ; R M S E=3.9725
\end{aligned}
$$

Pine-Hardwood:

$$
\begin{aligned}
& \widehat{S H}=124.01(1-\exp (-0.024058 A-0.022695 S I))^{10.187} \\
& N=23 ; R^{2}=0.863 ; R M S E=10.7087
\end{aligned}
$$

Hardwood-Pine:

$$
\begin{aligned}
& \widehat{S H}=113.12(1-\exp (-0.028269 A-0.026317 S I))^{12.221} \\
& N=26 ; R^{2}=0.678 ; R M S E=7.0133
\end{aligned}
$$

Hardwoods:

$$
\begin{aligned}
& \widehat{S H}=115.71(1-\exp (-0.024951 A-0.029544 S I))^{15.256} \\
& N=101 ; R^{2}=0.815 ; R M S E=8.8466
\end{aligned}
$$

Cypress-Tupelo:

$$
\begin{aligned}
& \widehat{S H}=104.85(1-\exp (-0.081933 A-0.039090 S I))^{2215.0} \\
& N=5 ; R^{2}=0.981 ; R M S E=1.8390
\end{aligned}
$$

\section{Canopy Bulk Density}

By far the most difficult variable to calculate, canopy bulk density $(C B D)$ in $\mathrm{lb} / \mathrm{ft}^{3}$ is generally understood to be the mass per unit volume of canopy biomass that would burn in a crown fire. This crown fuel primarily consists of foliage and twigs less than 0.12 inches $(0.3 \mathrm{~cm})$ in diameter and some portion of the live and dead branch wood less than 0.25 inches $(0.6 \mathrm{~cm})$ in diameter 
(Keane et al. 2005, Scott and Reinhardt 2001). A number of instrument-based methods have been evaluated for determining $C B D$, such as the ceptometer and the spherical densiometer (Keane et al. 2005). But the most popular method for estimating CBD uses measurements of tree diameter, total height, and $H B L C$ to predict available crown fuel load (foliage+twig biomass) for every tree in a stand from allometric crown biomass equations (Keane et al. 1998, 2000). Canopy fuel load (sum of crown fuel loads) per unit area divided by canopy depth $(\mathrm{SH}-\mathrm{CBH})$ yields $C B D$. Because the Savannah River Site has approximately 70 tree species present, it was a laborious job carefully searching the literature for species-specific and regionally based crown biomass equations. Fortunately, I was able to locate allometric equations for the majority of species on site. There were a number of species, such as blue beech (Carpinus caroliniana Walt.), holly (Ilex opaca Ait.), Chinaberry (Melia azedarach L.), and mulberry (Morus spp.), where I was unable to find biomass equations, so I used the national-scale estimators of Jenkins et al. (2004). The primary sources for conifers are Hepp and Brister (1992) for loblolly pine (Pinus taeda L.), Baldwin and Saucier (1983) for longleaf pine (P. palustris P. Mill.), Lohrey (1984) for slash pine (P. elliottii Engelm.), Loomis et al. (1966) for shortleaf pine (P. echinata P. Mill.), McNab et al. (1985) for sand pine (P. clausa (Chapman ex Engelm.) Vasey ex Sarg.), Wendel (1960) for pond pine (P. serotina Michx.), Mitsch and Ewell (1979) for cypress (Taxodium spp.), and Norris et al. (2001) for eastern redcedar (Juniperus virginiana L.). For broadleaf species the primary sources are Clark, III et al. (1985, 1986a, 1986b) for oaks (Quercus spp.), hickories (Carya spp.), elms (Ulmus spp.), ashes (Fraxinus spp.), gums (Nyssa spp.), red maple (Acer rubrum L.), sycamore (Platanus occidentalis L.), and yellow-poplar (Liriodendron tulipifera L.); Jenkins et al. (2004) for miscellaneous hardwoods, Schlaegel (1982) for boxelder (Acer negundo L.), Boerner and Kost (1986) for dogwood (Cornus florida L.), Busing et al. (1993) for beech (Fagus grandifolia Ehrh.), Hocker and Early (1983) for eastern hophornbeam (Ostrya virginiana (P. Mill.) K. Koch), Martin et al. (1998) for sourwood (Oxydendrum arboreum (L.) DC.), and Young et al. (1980) for willow (Salix spp.).

The next step was to model the plot values of $C B D$ against the stand variables. Four groups (loblolly, longleaf, hardwoods, and cypress-tupelo) showed some curvilinearity in CBD against the stand variables and the other 3 groups (slash, pine-hardwood, hardwood-pine) had very linear trends. For the four groups with the curvilinear trends, the natural log transformation linearized the data. The general model form used was

$$
\widehat{\ln C B D}=b_{0}+b_{1} \ln A+b_{2} \ln B A+b_{3} \ln S I+b_{4} \ln N B+b_{5} \ln Y R S
$$

For the remaining three groups the general model form used was

$$
\widehat{C B D}=b_{0}+b_{1} A+b_{2} B A+b_{3} S I+b_{4} N B+b_{5} Y R S+2 \text {-way interactions }
$$

Stepwise regression was used to help determine specific equations. The two burn history variables, $N B$ and YRS, had no effect on $C B D$. Below are the equations for $C B D$ for each of the 7 forest type groups. Non-significant coefficients/variables have been dropped. To convert $C B D$ in $\mathrm{lb} / \mathrm{ft}^{3}$ to $\mathrm{kg} / \mathrm{m}^{3}$ multiply by 16.0185 . 
Loblolly:

$$
\begin{aligned}
& \widehat{\ln C B D}=-3.00460-0.48305 \ln A+0.85787 \ln B A-1.14064 \ln S I \\
& N=277 ; R^{2}=0.678 ; R M S E=0.3212
\end{aligned}
$$

Longleaf:

$$
\begin{aligned}
& \widehat{\ln C B D}=-9.41785-0.34737 \ln A+1.11667 \ln B A \\
& N=129 ; R^{2}=0.843 ; R M S E=0.3120
\end{aligned}
$$

Slash:

$$
\begin{aligned}
& \widehat{C B D}=0.00049677+7.27442 \times 10^{-7} A \times B A \\
& N=58 ; R^{2}=0.563 ; R M S E=0.00112
\end{aligned}
$$

Pine-Hardwood:

$$
\begin{aligned}
& \widehat{C B D}=0.00039438+7.532 \times 10^{-5} B A-5.41041 \times 10^{-7} B A \times S I \\
& N=23 ; R^{2}=0.623 ; R M S E=0.00116
\end{aligned}
$$

Hardwood-Pine:

$$
\begin{aligned}
& \widehat{C B D}=-0.03292+0.00023188 B A+0.00051652 S I-2.16 \times 10^{-6} \mathrm{~A} \times S I \\
&+1.39 \times 10^{-6} \mathrm{~A} \times \mathrm{BA}-3.37 \times 10^{-6} \mathrm{BA} \times \mathrm{SI} \\
& N=25 ; R^{2}=0.559 ; R M S E=0.00112
\end{aligned}
$$

Hardwoods:

$$
\begin{aligned}
& \widehat{\ln C B D}=-5.16282-0.34624 \ln A+0.96580 \ln B A-0.86870 \ln S I \\
& N=102 ; R^{2}=0.316 ; R M S E=0.5002
\end{aligned}
$$

Cypress-Tupelo:

$$
\begin{aligned}
& \widehat{\ln C B D}=-4.17734-0.17291 \ln A+0.13735 \ln B A-0.26077 \ln S I \\
& N=5 ; R^{2}=0.414 ; R M S E=0.07046
\end{aligned}
$$

\section{Discussion}

From Table 2 we see that loblolly stands ranged from 2 to 100 years of age with a mean of 33 years. This age spread is also reflected in the stand basal areas from $1 \mathrm{ft}^{2}$ (recently harvested stands) to over $200 \mathrm{ft}^{2}$ for the older dense stands. Longleaf stands averaged 38 years of age, with a spread of 1 to 88 years but with a much lower mean $B A\left(72 \mathrm{ft}^{2}\right)$ compared to loblolly $\left(108 \mathrm{ft}^{2}\right)$. Slash pine stands averaged 44 years of age, and ranged from 4 to 62 years, and is less 
represented in ages than loblolly and longleaf. In looking across all forest type groups, the site indexes run from 40 to $110 \mathrm{ft}$ with a median of 80 to 90 for all groups. So there is a range of site productivity from low (40-50 ft) to high (100-110). Only slash stands occurred on a somewhat uniform series of site productivities, from 60-90 ft. Prescribed burning occurred on all forest types except cypress-tupelo. The pine-hardwood stands had a mean age of 47 years, and the hardwood-pine and hardwoods stands were both around 54 years. There were no early successional hardwood-pine stands, the youngest age being 21 years. Basal area averaged $81 \mathrm{ft}^{2}$ for the pine-hardwood stands, but the hardwood-pine and hardwoods stands had fairly high basal areas, averaging around $115 \mathrm{ft}^{2}$. In looking closely at the values in Table 2, we see that extensive ranges occur in the data. Broad coverage of values is important to capture the natural variability on the landscape and to develop statistically sound models (see caveat for cypress-tupelo data).

It is important to note that there are only 5 observations for the cypress-tupelo stands, so the data is very limited and should not be used for comparison against the other forest types. As information is generally lacking for canopy fuel for eastern forests, this data is included to give general trends, and the canopy parameter models fitted to this data should be used with caution.

Table 1 shows the averages and ranges of the four canopy characteristics by forest type. Canopy cover has the highest average in loblolly at $75 \%$, even though loblolly stands have the lowest mean age at 33 years. This is probably reflective of the higher basal areas carried in the loblolly stands compared to the longleaf, slash and pine-hardwood stands. The hardwood-pine and hardwoods stands have mean CCs only slightly lower than loblolly and similarly high mean BAs. The values for the canopy parameters $C B H$ and $S H$ are in line with expectations based on the values of stand variables shown in Table 1. Fore example, slash pine stands have an average age of 44 years and an average $S I$ (base age 50) of $84 \mathrm{ft}$. We would expect average $S H$ to be less than $84 \mathrm{ft}$ and in fact it is about $81 \mathrm{ft}$. Canopy bulk density values are very similar for the 3 pine types. The standard deviations are all about the same $\left(\approx 0.0017 \mathrm{lb} / \mathrm{ft}^{3}\right)$ as are the maximum values $\left(\approx 0.008 \mathrm{lb} / \mathrm{ft}^{3}\right)$. For the hardwoods and hardwood-pine stands, $C B D$ has greater variance, due no doubt to the large mix of species. The standard deviation for the hardwood-pine stands is $0.0038 \mathrm{lb} / \mathrm{ft}^{3}$, more than twice that of the pine types. Broadleaf stands in the eastern U.S. do not typically burn, but the potential exists. I report computed CBD based on summer foliage. A number of researchers assign a null value to bulk density for some species of hardwoods (Elizabeth Reinhardt, personal communication, JAN 2007)) because they are not considered as available fuel. This is a question that needs further consideration.

Canopy cover was accurately predicted using a logistic function. The $R^{2} \mathrm{~s}$ ranged from 0.47 for hardwoods to 0.71 for loblolly and slash. Not surprisingly, stand age and basal area were the predominate predictor variables, but site index played a role with longleaf and the pinehardwood and hardwood-pine types. In general burning had no effect on CC except in the pinehardwood type. The canopy parameters stand height and crown base height were well predicted using the Bertalanffy-Richards function. Age, basal area, and site index all played a significant role in predicting $C B H$ and $S H$. For $C B H$, coefficients of determination ranged from about 0.47 for the slash and hardwood-pine types to nearly 0.72 for longleaf. As might be expected, the regressions for $S H$ had relatively high $R^{2}$ values compared to the other canopy characteristics, with a low of 0.68 for the hardwood-pine type to $0.87-0.90$ for the pine-types. Burn history had an effect on crown base height, especially for the pine types. Unburned pine stands had slightly 
lower $C B H$ values. The trends for $C C, C B H$ and $S H$ were curvilinear, but not so for $C B D$. Canopy bulk density trends were adequately modeled with linear functions. The hardwoods type had a low fit $\left(R^{2}=0.32\right)$ but the other forest types had coefficients of determination above 0.55 and the longleaf regression had an excellent fit with $R^{2}=0.84$. Prescribed burning had no discernable effect on $C B D$ but the other stand variables were critical predictor variables.

Correlations were moderate to strong among the canopy characteristics and the stand variables of age, site index and basal area. Burn history had an effect on $C B H$ for the pine types, and shows the positive influence of having a burning program. The models presented provide critical information to fill data layers required for fire behavior models and aid in assessment of crown fire potential.

\section{Literature Cited}

Baldwin, V.C., Jr. and J.R. Saucier. 1983. Aboveground weight and volume of unthinned, planted longleaf pine on west Gulf forest sites. Res. Pap. SO-191. New Orleans, LA: U.S. Department of Agriculture, Forest Service, Southern Forest Experiment Station. 25 p.

Bechtold, W.A. 2003. Crown-diameter prediction models for 87 species of stand-grown trees in the Eastern United States. South. J. Appl. For. 27(4):269-278.

Boerner, R. and J. Kost. 1986. Biomass equations for flowering dogwood, Cornus florida L. Castanea 51:153-155.

Busing, R.T., E.E.C. Clebsch and P.S. White. 1993. Biomass and production of southern Appalachian cove forests reexamined. Can. J. For. Res. 23:760-765.

Clark, A., III, D.R. Philips and D.J. Frederick. 1985. Weight, volume, and physical properties of major hardwood species in the Gulf and Atlantic Coastal Plains. Res. Pap. SE-250. Asheville, NC: U.S. Department of Agriculture, Forest Service, Southeastern Forest Experiment Station. $66 \mathrm{p}$.

Clark, A., III, D.R. Philips and D.J. Frederick. 1986a. Weight, volume, and physical properties of major hardwood species in the Piedmont. Res. Pap. SE-255. Asheville, NC: U.S. Department of Agriculture, Forest Service, Southeastern Forest Experiment Station. 78 p.

Clark, A., III, D.R. Philips and D.J. Frederick. 1986b. Weight, volume, and physical properties of major hardwood species in the Upland-South. Res. Pap. SE-257. Asheville, NC: U.S. Department of Agriculture, Forest Service, Southeastern Forest Experiment Station. 55 p.

Crookston, N.L. and A.R. Stage. 1999. Percent canopy cover and stand structure statistics from the Forest Vegetation Simulator. Gen. Tech. Rep. RMRS-GTR-24. Ogden, UT: U.S. Department of Agriculture, Forest Service, Rocky Mountain Research Station. 11 p. 
Fulé, P.Z., J.E. Crouse, A.E. Cocke, M.M. Moore and W.W. Covington. 2004. Changes in canopy fuels and potential fire behavior 1880-2040: Grand Canyon, Arizona. Ecol. Model. 175:231-248.

Hepp, T.E. and G.H. Brister. 1982. Estimating crown biomass in loblolly pine plantations in the Carolina flatwoods. For. Sci. 28(1):115-127.

Hocker, H.W. and D.J. Early. 1983. Biomass and leaf area equations for northern forest species. Res. Pap. 102. Durham, NH: University of New Hampshire Agricultural Experiment Station.

Jenkins, J.C., D.C. Chojnacky, L.S. Heath and R.A. Birdsey. 2004. Comprehensive database of diameter-based biomass regressions for North American tree species. Gen. Tech. Rep. NE-319. Newtown Square, PA: U.S. Department of Agriculture, Forest Service, Northeastern Research Station. 45 p. [1 CD-ROM].

Jennings, S.B., N.D. Brown and D. Sheil. 1999. Assessing forest canopies and understorey illumination: canopy closure, canopy cover and other measures. Forestry 72(1):59-73.

Keane, R.E., J.L. Garner, K.M. Schmidt, D.G. Long, J.P. Menakis and M.A. Finney. 1998. Development of input spatial data layers for the FARSITE fire growth model for the SelwayBitterroot Wilderness complex, USA. Gen. Tech. Rep. RMRS-GTR-3. Ogden, UT: U.S. Department of Agriculture, Forest Service, Rocky Mountain Research Station. 121 p.

Keane, R. E.; S.A. Mincemoyer, K.M. Schmidt, D.G. Long and J.L. Garner. 2000. Mapping vegetation and fuels for fire management on the Gila National Forest Complex, New Mexico, [CD-ROM]. Gen. Tech. Rep. RMRS-GTR-46-CD. Ogden, UT: U.S. Department of Agriculture, Forest Service, Rocky Mountain Research Station. 126 p.

Keane, R.E., E.D. Reinhardt, J. Scott, K. Gray and J. Reardon. 2005. Estimating forest canopy bulk density using six indirect methods. Can. J. For. Res. 35:724-739.

Lohrey. 1984. Aboveground biomass of planted and direct-seeded slash pine in the west Gulf region. Proc. 6th Annual Southern Forest Biomass Workshop, Athens, GA, June 5-7, 1984. Saucier, J.R., Editor. Asheville, NC: U.S. Department of Agriculture, Forest Service, Southeastern Forest Experiment Station. Pp. 75-82.

Loomis, R.M., R.E. Phares and J.S. Crosby. 1966. Estimating foliage and branchwood quantities in shortleaf pine. For Sci 12(1):30-39.

Martin, J.G., B.D. Kloeppel, T.L. Schaefer, D.L. Kimbler, and S.G. McNulty. 1998. Aboveground biomass and nitrogen allocation of ten deciduous southern Appalachian tree species. Can. J. For. Res. 28:1648-1659.

McElhinny, C., P. Gibbons, C. Brack and J. Bauhus. 2005. Forest and woodland stand structural complexity: Its definition and measurement. For. Ecol. Manage. 218:1-24. 
McNab, W.H., K.W. Outcalt and R.H. Brendemuehl. 1985. Weight and volume of plantationgrown Choctawhatchee sand pine. Res. Pap. SE-252. Asheville, NC: U.S. Department of Agriculture, Forest Service, Southeastern Forest Experiment Station. 44 p.

Mitsch, W.J. and K.C. Ewell. 1979. Comparative biomass and growth of cypress in Florida wetlands. Am. Midl. Nat. 101(2):417-426.

Norris, M.D., J.M. Blair, L.C. Johnson and R.B. McKane. 2001. Assessing changes in biomass, productivity, and $\mathrm{C}$ and $\mathrm{N}$ stores following Juniperus virginiana forest expansion into tallgrass prairie. Can. J. For. Res. 31:1940-1946.

Schlaegel, B.E. 1982. Boxelder (Acer negundo L.) biomass component regression analysis for the Mississippi Delta. For. Sci. 28(2):355-358.

Scott, J.H. and E.D. Reinhardt. 2001. Assessing crown fire potential by linking models of surface and crown fire behavior. Res. Pap. RMRS-RP-29. Fort Collins, CO: U.S. Department of Agriculture, Forest Service, Rocky Mountain Research Station. 59 p.

Wendel, G.W. 1960. Fuel weights of pond pine crowns. Res. Note SE-149. Asheville, NC: U.S. Department of Agriculture, Forest Service, Southeastern Forest Experiment Station. 2 p.

Young, H.E. J.H. Ribe and K. Wainwright. 1980. Weight tables for tree and shrub species in Maine. Misc. Rep. 230. Orono, ME: University of Maine, Life Sciences and Agriculture Experiment Station. 


\section{Appendix}

Canopy Parameters and Stand-level Variables 


\section{DE- AI09-00SR22188 TECHNICAL REPORT 2007 07-16-R}

\begin{tabular}{|c|c|c|c|c|c|c|c|c|c|c|c|}
\hline 1001 & 0.6476 & 25 & 70.60 & 0.00294 & 0.047 & 2 & 4 & 2 Longleaf pine & 44 & 80 & 116.61 \\
\hline 1002 & 0.4388 & 35 & 64.57 & 0.00228 & 0.036 & 2 & 4 & 2 Longleaf pine & 41 & 70 & 55.02 \\
\hline 1003 & 0.6395 & 26 & 58.11 & 0.00326 & 0.052 & 4 & 2 & 2 Longleaf pine & 34 & 60 & 86.16 \\
\hline 1004 & 0.1895 & 15 & 26.00 & 0.00091 & 0.015 & 3 & 2 & 2 Longleaf pine & 6 & 60 & 15.64 \\
\hline 1005 & 0.5082 & 40 & 95.00 & 0.00206 & 0.033 & 2 & 2 & 1 Loblolly pine & 45 & 100 & 137.41 \\
\hline 1006 & 0.2180 & 8 & 50.33 & 0.00261 & 0.042 & 0 & 33 & 6 Hardwoods & 31 & 70 & 96.73 \\
\hline 1007 & 0.9619 & 1 & 12.91 & 0.00368 & 0.059 & 0 & 33 & 1 Loblolly pine & 6 & 90 & 25.85 \\
\hline 1008 & 0.5962 & 31 & 88.75 & 0.00381 & 0.061 & 0 & 33 & 4 Pine-hdwd mix & 72 & 80 & 135.38 \\
\hline 1009 & 0.0535 & 35 & 62.00 & 0.00033 & 0.005 & 0 & 33 & 4 Pine-hdwd mix & 52 & 60 & 15.00 \\
\hline 1010 & 0.5477 & 37 & 64.89 & 0.00424 & 0.068 & 0 & 33 & 1 Loblolly pine & 43 & 70 & 114.94 \\
\hline 1011 & 0.9841 & 11.5 & 29.11 & 0.00557 & 0.089 & 1 & 29 & 2 Longleaf pine & 12 & 70 & 105.79 \\
\hline 1012 & 0.3768 & 37 & 66.83 & 0.00264 & 0.042 & 1 & 20 & 2 Longleaf pine & 36 & 70 & 60.33 \\
\hline 1013 & 0.5848 & 9 & 32.60 & 0.00256 & 0.041 & 2 & 4 & 1 Loblolly pine & 11 & 70 & 42.29 \\
\hline 1014 & 0.6529 & 36 & 78.55 & 0.00247 & 0.040 & 2 & 4 & 2 Longleaf pine & 41 & 90 & 90.84 \\
\hline 1015 & 0.5651 & 39 & 79.60 & 0.00316 & 0.051 & 2 & 4 & 2 Longleaf pine & 50 & 80 & 106.44 \\
\hline 1016 & 0.2070 & 10 & 70.00 & 0.00259 & 0.041 & 2 & 4 & 6 Hardwoods & 54 & 60 & 80.27 \\
\hline 1017 & 0.9066 & 52 & 93.00 & 0.00639 & 0.102 & 2 & 4 & 2 Longleaf pine & 73 & 80 & 209.62 \\
\hline 1018 & 0.6799 & 33 & 84.56 & 0.00307 & 0.049 & 0 & 33 & 5 Hdwd-pine mix & 51 & 90 & 105.89 \\
\hline 1019 & 0.7468 & 23 & 86.00 & 0.00335 & 0.054 & 0 & 33 & 1 Loblolly pine & 39 & 90 & 183.13 \\
\hline 1020 & 0.4216 & 31 & 63.86 & 0.00155 & 0.025 & 3 & 4 & 2 Longleaf pine & 65 & 60 & 52.50 \\
\hline 1021 & 0.6246 & 12 & 32.13 & 0.00239 & 0.038 & 4 & 4 & 2 Longleaf pine & 40 & 50 & 52.21 \\
\hline 1022 & 0.7219 & 11 & 62.30 & 0.00366 & 0.059 & 2 & 6 & 2 Longleaf pine & 51 & 70 & 137.19 \\
\hline 1023 & 0.7255 & 26 & 62.91 & 0.00306 & 0.049 & 2 & 6 & 2 Longleaf pine & 35 & 80 & 95.77 \\
\hline 1024 & 0.6510 & 44 & 69.92 & 0.00446 & 0.071 & 2 & 6 & 2 Longleaf pine & 82 & 60 & 97.50 \\
\hline 1025 & 0.9949 & 36 & 70.46 & 0.00370 & 0.059 & 1 & 7 & 6 Hardwoods & 51 & 80 & 131.66 \\
\hline 1026 & 0.9207 & 5 & 33.38 & 0.00112 & 0.018 & 2 & 7 & 2 Longleaf pine & 38 & 60 & 32.83 \\
\hline 1027 & 0.7744 & 6 & 22.33 & 0.00265 & 0.042 & 0 & 33 & 1 Loblolly pine & 9 & 90 & 31.27 \\
\hline 1028 & 0.7620 & 14 & 53.00 & 0.00203 & 0.033 & 2 & 0.5 & 1 Loblolly pine & 22 & 80 & 80.29 \\
\hline 1029 & 0.4056 & 30 & 70.14 & 0.00183 & 0.029 & 1 & 7 & 2 Longleaf pine & 45 & 70 & 66.55 \\
\hline 1030 & 0.9781 & 14 & 37.58 & 0.00533 & 0.085 & 1 & 32 & 1 Loblolly pine & 10 & 70 & 89.86 \\
\hline
\end{tabular}




\section{DE- AI09-00SR22188 TECHNICAL REPORT}

\begin{tabular}{ll}
1031 & 0.3725 \\
1032 & 0.5262 \\
1033 & 0.9090 \\
1034 & 0.9821 \\
1035 & 0.6381 \\
1036 & 0.9381 \\
1037 & 0.6295 \\
1038 & 0.9618 \\
1039 & 0.6846 \\
1040 & 0.6881 \\
1041 & 0.9019 \\
1042 & 0.6545 \\
1043 & 0.8134 \\
1044 & 0.9286 \\
1045 & 0.9786 \\
1046 & 0.9015 \\
1047 & 0.9612 \\
1048 & 0.5526 \\
1050 & 0.9733 \\
1051 & 0.8339 \\
1052 & 0.6880 \\
1053 & 0.6432 \\
1054 & 0.9073 \\
1055 & 0.2864 \\
1056 & 0.7982 \\
1057 & 0.7664 \\
1058 & 0.5618 \\
1059 & 0.8892 \\
1060 & 0.9908 \\
1061 & 0.4766 \\
1063 & 0.7299 \\
1064 & 0.5886 \\
& \\
\hline
\end{tabular}

$\begin{array}{rllll}19 & 67.83 & 0.00675 & 0.108 & 2 \\ 9 & 47.33 & 0.00323 & 0.052 & 2 \\ 13 & 53.50 & 0.00293 & 0.047 & 3 \\ 21 & 45.79 & 0.00647 & 0.104 & 3 \\ 48.5 & 97.73 & 0.00535 & 0.086 & 1 \\ 10 & 37.11 & 0.00627 & 0.100 & 2 \\ 13 & 55.50 & 0.00243 & 0.039 & 1 \\ 18 & 53.92 & 0.00620 & 0.099 & 2 \\ 13 & 50.11 & 0.00336 & 0.054 & 2 \\ 21 & 57.22 & 0.00212 & 0.034 & 2 \\ 6.5 & 28.25 & 0.00441 & 0.071 & 2 \\ 7.5 & 41.14 & 0.00274 & 0.044 & 0 \\ 9 & 49.00 & 0.00295 & 0.047 & 2 \\ 10 & 28.50 & 0.00776 & 0.124 & 0 \\ 30 & 60.38 & 0.00585 & 0.094 & 2 \\ 35 & 58.93 & 0.00381 & 0.061 & 2 \\ 4 & 19.20 & 0.00452 & 0.072 & 2 \\ 43.5 & 75.20 & 0.00466 & 0.075 & 1 \\ 17 & 41.33 & 0.00663 & 0.106 & 1 \\ 46 & 89.21 & 0.00408 & 0.065 & 2 \\ 22 & 78.78 & 0.00459 & 0.074 & 1 \\ 38.5 & 85.89 & 0.00409 & 0.065 & 0 \\ 6.5 & 49.82 & 0.00120 & 0.019 & 0 \\ 25 & 43.50 & 0.00172 & 0.028 & 3 \\ 18.5 & 40.20 & 0.00287 & 0.046 & 1 \\ 23 & 47.88 & 0.00356 & 0.057 & 1 \\ 28.5 & 86.63 & 0.00235 & 0.038 & 2 \\ 52 & 93.60 & 0.00224 & 0.036 & 1 \\ 28 & 93.21 & 0.00287 & 0.046 & 1 \\ 16 & 67.29 & 0.00420 & 0.067 & 2 \\ 45 & 79.54 & 0.00271 & 0.043 & 3 \\ 5 & 18.50 & 0.00127 & 0.020 & 2\end{array}$

$\begin{array}{lrrr}\text { 2 Longleaf pine } & 33 & 80 & 111.46 \\ \text { 4 Pine-hdwd mix } & 33 & 75 & 32.80 \\ \text { 1 Loblolly pine } & 20 & 90 & 129.43 \\ \text { 1 Loblolly pine } & 21 & 70 & 153.40 \\ \text { 1 Loblolly pine } & 68 & 90 & 150.14 \\ \text { 4 Pine-hdwd mix } & 44 & 60 & 105.06 \\ \text { 2 Longleaf pine } & 81 & 60 & 86.37 \\ \text { 2 Longleaf pine } & 29 & 70 & 144.10 \\ \text { 2 Longleaf pine } & 33 & 60 & 98.64 \\ \text { 2 Longleaf pine } & 38 & 80 & 69.92 \\ \text { 6 Hardwoods } & 47 & 50 & 55.84 \\ \text { 2 Longleaf pine } & 50 & 50 & 86.59 \\ \text { 6 Hardwoods } & 66 & 50 & 123.64 \\ \text { 1 Loblolly pine } & 9 & 90 & 87.59 \\ \text { 1 Loblolly pine } & 24 & 80 & 142.50 \\ \text { 1 Loblolly pine } & 24 & 80 & 105.00 \\ \text { 1 Loblolly pine } & 5 & 80 & 36.56 \\ \text { 2 Longleaf pine } & 39 & 80 & 90.00 \\ \text { 1 Loblolly pine } & 11 & 70 & 126.57 \\ \text { 1 Loblolly pine } & 57 & 80 & 176.17 \\ \text { 6 Hardwoods } & 50 & 80 & 124.13 \\ \text { 5 Hdwd-pine mix } & 45 & 100 & 108.27 \\ \text { 6 Hardwoods } & 47 & 80 & 87.16 \\ \text { 2 Longleaf pine } & 47 & 60 & 31.53 \\ \text { 2 Longleaf pine } & 26 & 70 & 56.46 \\ \text { 2 Longleaf pine } & 30 & 60 & 58.09 \\ \text { 5 Hdwd-pine mix } & 57 & 70 & 115.93 \\ \text { 1 Loblolly pine } & 48 & 90 & 127.50 \\ \text { 5 Hdwd-pine mix } & 56 & 80 & 149.90 \\ \text { 5 Hdwd-pine mix } & 57 & 70 & 112.65 \\ \text { 2 Longleaf pine } & 67 & 70 & 97.50 \\ \text { 4 Pine-hdwd mix } & 9 & 60 & 13.16\end{array}$




\section{DE- AI09-00SR22188 TECHNICAL REPORT}

$\begin{array}{ll}1065 & 0.9254 \\ 1066 & 0.7286 \\ 1067 & 0.4600 \\ 1068 & 0.2873 \\ 1069 & 0.5466 \\ 1070 & 0.3927 \\ 1071 & 0.7854 \\ 1072 & 0.9819 \\ 1073 & 0.9714 \\ 1074 & 0.9536 \\ 1075 & 0.4852 \\ 1076 & 0.6623 \\ 1077 & 0.5352 \\ 1078 & 0.8461 \\ 1079 & 0.6383 \\ 1080 & 0.5363 \\ 1082 & 0.6967 \\ 1083 & 0.5510 \\ 1084 & 0.7851 \\ 1085 & 0.3074 \\ 1086 & 0.6451 \\ 1087 & 0.7788 \\ 1088 & 0.5814 \\ 1089 & 0.7449 \\ 1090 & 0.7088 \\ 1091 & 0.9759 \\ 1092 & 0.9440 \\ 1093 & 0.7873 \\ 1094 & 0.3980 \\ 1095 & 0.6436 \\ 1096 & 0.4991 \\ 1097 & 0.3161\end{array}$

$\begin{array}{rrrr}21 & 42.18 & 0.00496 & 0.079 \\ 43 & 73.10 & 0.00248 & 0.040 \\ 36 & 98.38 & 0.00159 & 0.025 \\ 42.5 & 76.75 & 0.00069 & 0.011 \\ 11 & 61.83 & 0.00657 & 0.105 \\ 48 & 85.57 & 0.00172 & 0.028 \\ 62 & 98.00 & 0.00819 & 0.131 \\ 52.5 & 105.07 & 0.00831 & 0.133 \\ 3 & 13.09 & 0.00126 & 0.020 \\ 30 & 57.92 & 0.00553 & 0.089 \\ 30 & 86.63 & 0.00289 & 0.046 \\ 69 & 99.58 & 0.00240 & 0.038 \\ 19.5 & 62.14 & 0.00210 & 0.034 \\ 28 & 83.83 & 0.00706 & 0.113 \\ 35 & 95.78 & 0.00229 & 0.037 \\ 10 & 57.00 & 0.00161 & 0.026 \\ 10.5 & 26.50 & 0.00433 & 0.069 \\ 41.5 & 72.56 & 0.00433 & 0.069 \\ 31 & 57.36 & 0.00318 & 0.051 \\ 3 & 10.00 & 0.00044 & 0.007 \\ 44 & 91.55 & 0.00255 & 0.041 \\ 50 & 85.85 & 0.00198 & 0.032 \\ 37.5 & 78.90 & 0.00511 & 0.082 \\ 29 & 50.70 & 0.00410 & 0.066 \\ 35.5 & 78.63 & 0.00356 & 0.057 \\ 27.5 & 52.46 & 0.00570 & 0.091 \\ 45.5 & 88.80 & 0.00218 & 0.035 \\ 56 & 93.77 & 0.00314 & 0.050 \\ 33 & 82.86 & 0.00242 & 0.039 \\ 50 & 73.17 & 0.00659 & 0.105 \\ 35.5 & 77.50 & 0.00275 & 0.044 \\ 16.5 & 71.20 & 0.00172 & 0.028\end{array}$

1 Loblolly pine
1 Loblolly pine
1 Loblolly pine
1 Loblolly pine
4 Pine-hdwd mix
2 Longleaf pine
1 Loblolly pine
5 Hdwd-pine mix
2 Longleaf pine
2 Longleaf pine
1 Loblolly pine
1 Loblolly pine
6 Hardwoods
6 Hardwoods
6 Hardwoods
1 Loblolly pine
1 Loblolly pine
2 Longleaf pine
1 Loblolly pine
2 Longleaf pine
1 Loblolly pine
1 Loblolly pine
2 Longleaf pine
1 Loblolly pine
4 Pine-hdwd mix
1 Loblolly pine
1 Loblolly pine
1 Loblolly pine
1 Loblolly pine
1 Longleaf pine
1 Lolly pine
1 pine




\section{DE- AI09-00SR22188 TECHNICAL REPORT}

\begin{tabular}{|c|c|c|c|c|c|}
\hline 1098 & 0.5574 & 52.5 & 93.30 & 0.00248 & 0.040 \\
\hline 1099 & 0.9313 & 54.5 & 89.56 & 0.00683 & 0.109 \\
\hline 1107 & 0.8683 & 46 & 79.93 & 0.00459 & 0.073 \\
\hline 1108 & 0.2889 & 39 & 79.40 & 0.00109 & 0.018 \\
\hline 1109 & 0.7132 & 34 & 87.62 & 0.00180 & 0.029 \\
\hline 1110 & 0.6828 & 46.5 & 95.55 & 0.00333 & 0.053 \\
\hline 1111 & 0.9848 & 21.5 & 44.13 & 0.00640 & 0.103 \\
\hline 1114 & 0.9883 & 47 & 97.71 & 0.00636 & 0.102 \\
\hline 1115 & 0.0611 & 28 & 76.00 & 0.00016 & 0.003 \\
\hline 1116 & 0.5921 & 46 & 79.90 & 0.00248 & 0.040 \\
\hline 1117 & 0.5462 & 36 & 80.63 & 0.00321 & 0.051 \\
\hline 1118 & 0.7271 & 54 & 91.08 & 0.00524 & 0.084 \\
\hline 1120 & 0.9124 & 15 & 37.36 & 0.00620 & 0.099 \\
\hline 1121 & 0.9242 & 27.5 & 56.85 & 0.00344 & 0.055 \\
\hline 1122 & 0.9301 & 40 & 73.35 & 0.00590 & 0.095 \\
\hline 1123 & 0.5816 & 45 & 79.56 & 0.00375 & 0.060 \\
\hline 1124 & 0.8911 & 39 & 72.36 & 0.00460 & 0.074 \\
\hline 1126 & 0.4934 & 21 & 77.80 & 0.00262 & 0.042 \\
\hline 1127 & 0.6665 & 27 & 90.44 & 0.00148 & 0.024 \\
\hline 1128 & 0.5510 & 30 & 79.00 & 0.00279 & 0.045 \\
\hline 1129 & 0.9564 & 34 & 80.71 & 0.00320 & 0.051 \\
\hline 1130 & 0.9504 & 40 & 91.00 & 0.00756 & 0.121 \\
\hline 1131 & 0.2826 & 14 & 54.00 & 0.00054 & 0.009 \\
\hline 1132 & 0.8457 & 29 & 61.08 & 0.00297 & 0.048 \\
\hline 1133 & 0.5400 & 27 & 82.78 & 0.00208 & 0.033 \\
\hline 1134 & 0.9825 & 20.5 & 48.13 & 0.00606 & 0.097 \\
\hline 1136 & 0.7264 & 14 & 64.75 & 0.00520 & 0.083 \\
\hline 1138 & 0.9249 & 31.5 & 59.88 & 0.00444 & 0.071 \\
\hline 1139 & 0.6541 & 27 & 79.27 & 0.00288 & 0.046 \\
\hline 1140 & 0.2808 & 48 & 76.20 & 0.00168 & 0.027 \\
\hline 1141 & 0.7832 & 48.5 & 108.21 & 0.00250 & 0.040 \\
\hline 1142 & 0.2167 & 7 & 85.50 & 0.00090 & 0.014 \\
\hline
\end{tabular}

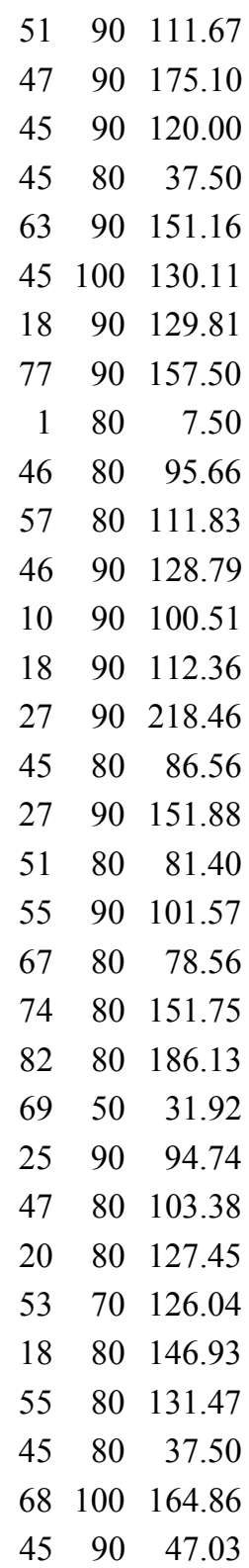




\section{DE- AI09-00SR22188 TECHNICAL REPORT}

$\begin{array}{ll}1143 & 0.7649 \\ 1144 & 0.9488 \\ 1145 & 0.7782 \\ 1147 & 0.3866 \\ 1148 & 0.3668 \\ 1149 & 0.7812 \\ 1150 & 0.5979 \\ 1151 & 0.5636 \\ 1152 & 0.2007 \\ 1154 & 0.5138 \\ 1156 & 0.7898 \\ 1157 & 0.6572 \\ 1158 & 0.9573 \\ 1159 & 0.9067 \\ 1160 & 0.9466 \\ 1161 & 0.7324 \\ 1162 & 0.9301 \\ 1163 & 0.9757 \\ 1164 & 0.2976 \\ 1165 & 0.4333 \\ 1166 & 0.7852 \\ 1167 & 0.9429 \\ 1169 & 0.7769 \\ 1171 & 0.7212 \\ 1172 & 0.9349 \\ 1173 & 0.9593 \\ 1174 & 0.8378 \\ 1175 & 0.9701 \\ 1176 & 0.9121 \\ 1177 & 0.4935 \\ 1180 & 0.6439 \\ 1181 & 0.7176\end{array}$

$\begin{array}{rrrr}45 & 85.92 & 0.00533 & 0.085 \\ 5 & 27.17 & 0.00252 & 0.040 \\ 32 & 74.25 & 0.00419 & 0.067 \\ 26 & 63.20 & 0.00382 & 0.061 \\ 44.5 & 79.33 & 0.00421 & 0.068 \\ 35 & 91.45 & 0.00263 & 0.042 \\ 32 & 91.30 & 0.00263 & 0.042 \\ 2.5 & 15.38 & 0.00091 & 0.015 \\ 11 & 58.67 & 0.00258 & 0.041 \\ 3.5 & 17.75 & 0.00067 & 0.011 \\ 36 & 67.92 & 0.00439 & 0.070 \\ 50 & 80.10 & 0.00416 & 0.067 \\ 16 & 42.11 & 0.00469 & 0.075 \\ 28 & 53.42 & 0.00359 & 0.057 \\ 3 & 12.08 & 0.00061 & 0.010 \\ 27 & 101.85 & 0.00137 & 0.022 \\ 29 & 89.67 & 0.00493 & 0.079 \\ 7 & 33.11 & 0.00254 & 0.041 \\ 43 & 80.20 & 0.00251 & 0.040 \\ 45 & 76.71 & 0.00176 & 0.028 \\ 47 & 93.14 & 0.00556 & 0.089 \\ 59.5 & 95.95 & 0.00280 & 0.045 \\ 15 & 53.64 & 0.00441 & 0.071 \\ 29.5 & 85.92 & 0.00349 & 0.056 \\ 30.5 & 65.57 & 0.00472 & 0.076 \\ 3 & 31.00 & 0.00155 & 0.025 \\ 36.5 & 94.50 & 0.00246 & 0.039 \\ 29 & 94.75 & 0.00297 & 0.048 \\ 16 & 72.15 & 0.00460 & 0.074 \\ 16 & 82.83 & 0.00166 & 0.027 \\ 47 & 80.89 & 0.00317 & 0.051 \\ 36 & 89.67 & 0.00409 & 0.066\end{array}$

$\begin{array}{lrrr}\text { 1 Loblolly pine } & 74 & 80 & 133.55 \\ \text { 2 Longleaf pine } & 12 & 80 & 54.78 \\ \text { 5 Hdwd-pine mix } & 34 & 90 & 87.47 \\ \text { 6 Hardwoods } & 48 & 60 & 59.66 \\ \text { 1 Loblolly pine } & 41 & 80 & 61.50 \\ \text { 6 Hardwoods } & 57 & 90 & 192.70 \\ \text { 3 Slash pine } & 47 & 90 & 103.67 \\ \text { 2 Longleaf pine } & 8 & 80 & 13.89 \\ \text { 1 Loblolly pine } & 52 & 80 & 48.72 \\ \text { 2 Longleaf pine } & 11 & 90 & 12.77 \\ \text { 1 Loblolly pine } & 28 & 80 & 130.29 \\ \text { 1 Loblolly pine } & 48 & 80 & 105.00 \\ \text { 1 Loblolly pine } & 17 & 90 & 106.05 \\ \text { 1 Loblolly pine } & 17 & 90 & 99.70 \\ \text { 2 Longleaf pine } & 9 & 90 & 9.31 \\ \text { 6 Hardwoods } & 55 & 100 & 172.38 \\ \text { 6 Hardwoods } & 74 & 80 & 182.01 \\ \text { 2 Longleaf pine } & 12 & 70 & 63.28 \\ \text { 3 Slash pine } & 41 & 80 & 60.00 \\ \text { 1 Loblolly pine } & 40 & 80 & 74.07 \\ \text { 3 Slash pine } & 45 & 90 & 151.21 \\ \text { 1 Loblolly pine } & 46 & 90 & 151.56 \\ \text { 2 Longleaf pine } & 41 & 70 & 132.32 \\ \text { 3 Slash pine } & 46 & 80 & 148.93 \\ \text { 1 Loblolly pine } & 28 & 80 & 151.07 \\ \text { 6 Hardwoods } & 16 & 90 & 42.67 \\ \text { 1 Loblolly pine } & 70 & 90 & 179.85 \\ \text { 6 Hardwoods } & 57 & 90 & 195.04 \\ \text { 5 Hdwd-pine mix } & 48 & 80 & 154.67 \\ \text { 6 Hardwoods } & 68 & 90 & 96.73 \\ \text { 3 Slash pine } & 42 & 90 & 88.72 \\ \text { 1 Loblolly pine } & 39 & 90 & 159.21 \\ & & & \\ & \end{array}$




\section{DE- AI09-00SR22188 TECHNICAL REPORT}

$\begin{array}{ll}1182 & 0.5368 \\ 1183 & 0.2480 \\ 1184 & 0.7243 \\ 1186 & 0.8403 \\ 1187 & 0.8119 \\ 1188 & 0.7215 \\ 1189 & 0.9104 \\ 1190 & 0.9996 \\ 1192 & 0.9007 \\ 1194 & 0.9198 \\ 1195 & 0.9622 \\ 1196 & 0.3023 \\ 1197 & 0.9383 \\ 1199 & 0.9257 \\ 1200 & 0.9271 \\ 1201 & 0.5160 \\ 1202 & 0.6980 \\ 1203 & 0.7009 \\ 1206 & 0.8842 \\ 1207 & 0.4026 \\ 1208 & 0.5992 \\ 1209 & 0.7391 \\ 1210 & 0.5477 \\ 1211 & 0.9634 \\ 1212 & 0.6401 \\ 1214 & 0.6221 \\ 1215 & 0.6922 \\ 1217 & 0.9268 \\ 1218 & 0.8209 \\ 1219 & 0.6324 \\ 1220 & 0.9511 \\ 1222 & 0.9043\end{array}$

$\begin{array}{rrrr}20 & 70.17 & 0.00257 & 0.041 \\ 18 & 73.75 & 0.00151 & 0.024 \\ 29 & 60.80 & 0.00334 & 0.054 \\ 13 & 47.40 & 0.00408 & 0.065 \\ 25 & 69.40 & 0.00313 & 0.050 \\ 37 & 93.18 & 0.00238 & 0.038 \\ 32.5 & 80.58 & 0.01403 & 0.225 \\ 13 & 34.82 & 0.00488 & 0.078 \\ 17 & 42.13 & 0.00610 & 0.098 \\ 27 & 81.64 & 0.00679 & 0.109 \\ 26 & 64.31 & 0.00335 & 0.054 \\ 10 & 28.50 & 0.00022 & 0.004 \\ 20 & 50.33 & 0.00393 & 0.063 \\ 42 & 75.74 & 0.00506 & 0.081 \\ 48 & 96.06 & 0.00625 & 0.100 \\ 23 & 92.57 & 0.00230 & 0.037 \\ 28 & 76.00 & 0.00394 & 0.063 \\ 34 & 78.82 & 0.00346 & 0.055 \\ 36 & 96.92 & 0.00517 & 0.083 \\ 61 & 96.71 & 0.00160 & 0.026 \\ 48 & 111.82 & 0.00135 & 0.022 \\ 37 & 99.54 & 0.00258 & 0.041 \\ 3 & 12.80 & 0.00090 & 0.014 \\ 17.5 & 53.93 & 0.00631 & 0.101 \\ 12 & 93.82 & 0.00186 & 0.030 \\ 12 & 34.00 & 0.00301 & 0.048 \\ 17.5 & 79.45 & 0.00336 & 0.054 \\ 17 & 50.17 & 0.00356 & 0.057 \\ 14.5 & 69.40 & 0.00239 & 0.038 \\ 51.5 & 106.45 & 0.00427 & 0.068 \\ 31.5 & 51.33 & 0.00679 & 0.109 \\ 53 & 90.93 & 0.00327 & 0.052\end{array}$

\begin{tabular}{l}
6 Hardwoods \\
1 Loblolly pine \\
2 Longleaf pine \\
1 Loblolly pine \\
6 Hardwoods \\
5 Hdwd-pine mix \\
6 Hardwoods \\
1 Loblolly pine \\
1 Loblolly pine \\
6 Hardwoods \\
5 Hdwd-pine mix \\
6 Hardwoods \\
1 Loblolly pine \\
1 Loblolly pine \\
6 Hardwoods \\
6 Hardwoods \\
6 Hardwoods \\
3 Slash pine \\
5 Hdwd-pine mix \\
1 Loblolly pine \\
5 Hdwd-pine mix \\
1 Loblolly pine \\
2 Longleaf pine \\
1 Loblolly pine \\
1 Loblolly pine \\
1 Loblolly pine \\
3 Slash pine \\
1 Loblolly pine \\
6 Hardwoods \\
1 Loblolly pine \\
1 Loblolly pine \\
1 Loblolly pine \\
\hline
\end{tabular}

$\begin{array}{lll}45 & 80 & 90.91\end{array}$

$\begin{array}{lll}45 & 80 & 57.49\end{array}$

$\begin{array}{lll}39 & 70 & 82.91\end{array}$

$\begin{array}{lll}18 & 90 & 111.04\end{array}$

$\begin{array}{lll}33 & 80 & 92.31\end{array}$

$\begin{array}{lll}57 & 90 & 172.66\end{array}$

$84 \quad 70 \quad 137.20$

$15 \quad 70 \quad 87.56$

$\begin{array}{lll}15 \quad 80 & 116.58\end{array}$

$\begin{array}{lll}38 & 100 & 117.09\end{array}$

$\begin{array}{lll}21 & 100 & 143.24\end{array}$

$27 \quad 60 \quad 8.96$

$19 \quad 80 \quad 111.46$

$\begin{array}{lll}27 & 90 & 176.61\end{array}$

$\begin{array}{lll}52 & 110 & 155.39\end{array}$

$\begin{array}{lll}35 & 90 & 114.68\end{array}$

$\begin{array}{lll}60 & 80 & 99.26\end{array}$

$\begin{array}{lll}43 & 80 & 133.11\end{array}$

$\begin{array}{lll}52 & 100 & 142.43\end{array}$

$\begin{array}{lll}46 \quad 90 & 60.84\end{array}$

$\begin{array}{lll}82 & 100 & 140.99\end{array}$

$\begin{array}{lll}47 & 100 & 159.74\end{array}$

$\begin{array}{lll}6 & 90 & 14.75\end{array}$

$\begin{array}{lll}20 & 80 & 151.85\end{array}$

$\begin{array}{lll}46 & 100 & 131.32\end{array}$

$\begin{array}{lll}12 & 70 & 47.72\end{array}$

$\begin{array}{lll}43 & 80 & 146.53\end{array}$

$\begin{array}{lll}11 & 90 & 118.50\end{array}$

$\begin{array}{lll}42 \quad 80 & 104.55\end{array}$

$\begin{array}{lll}50 & 100 & 166.58\end{array}$

$\begin{array}{lll}14 & 100 & 153.75\end{array}$

$\begin{array}{lll}50 & 90 & 162.83\end{array}$ 


\section{DE- AI09-00SR22188 TECHNICAL REPORT}

$\begin{array}{ll}1223 & 0.5092 \\ 1224 & 0.6220 \\ 1225 & 0.5608 \\ 1226 & 0.9369 \\ 1227 & 0.5773 \\ 1230 & 0.5277 \\ 1231 & 0.5796 \\ 1234 & 0.9201 \\ 1235 & 0.8150 \\ 1236 & 0.4961 \\ 1237 & 0.1330 \\ 1238 & 0.5028 \\ 1239 & 0.8130 \\ 1240 & 0.7336 \\ 1241 & 0.4696 \\ 1242 & 0.4591 \\ 1243 & 0.9167 \\ 1244 & 0.6699 \\ 1245 & 0.9644 \\ 1246 & 0.4439 \\ 1247 & 0.9243 \\ 1248 & 0.8933 \\ 1249 & 0.5992 \\ 1254 & 0.8000 \\ 1255 & 0.5427 \\ 1256 & 0.9893 \\ 1257 & 0.3576 \\ 1259 & 0.8825 \\ 1260 & 0.3852 \\ 1262 & 0.4727 \\ 1263 & 0.8624 \\ 1265 & 0.7051\end{array}$

$\begin{array}{rrrr}34 & 91.75 & 0.00220 & 0.035 \\ 20 & 96.86 & 0.00194 & 0.031 \\ 38.5 & 76.11 & 0.00354 & 0.057 \\ 68.5 & 103.84 & 0.00344 & 0.055 \\ 20 & 74.33 & 0.00453 & 0.073 \\ 13 & 90.67 & 0.00159 & 0.025 \\ 61 & 96.20 & 0.00195 & 0.031 \\ 43 & 85.82 & 0.00541 & 0.087 \\ 58 & 106.00 & 0.00290 & 0.046 \\ 14 & 54.60 & 0.00201 & 0.032 \\ 11 & 69.00 & 0.00032 & 0.005 \\ 48 & 83.63 & 0.00423 & 0.068 \\ 54 & 115.62 & 0.00350 & 0.056 \\ 29 & 93.40 & 0.00195 & 0.031 \\ 49 & 87.75 & 0.00119 & 0.019 \\ 54 & 87.25 & 0.00135 & 0.022 \\ 55 & 91.38 & 0.00265 & 0.043 \\ 64 & 103.25 & 0.00276 & 0.044 \\ 16 & 39.92 & 0.00470 & 0.075 \\ 29 & 80.00 & 0.00319 & 0.051 \\ 39 & 98.73 & 0.00279 & 0.045 \\ 19 & 81.56 & 0.00488 & 0.078 \\ 17 & 56.00 & 0.00335 & 0.054 \\ 7 & 25.88 & 0.00268 & 0.043 \\ 31 & 84.57 & 0.00218 & 0.035 \\ 34 & 53.82 & 0.00655 & 0.105 \\ 39 & 80.83 & 0.00382 & 0.061 \\ 43 & 92.20 & 0.00536 & 0.086 \\ 30.5 & 83.14 & 0.00170 & 0.027 \\ 11 & 55.83 & 0.00254 & 0.041 \\ 46 & 91.92 & 0.00280 & 0.045 \\ 42.5 & 88.11 & 0.00390 & 0.062\end{array}$

$\begin{array}{lrrr}\text { 6 Hardwoods } & 81 & 90 & 131.12 \\ \text { 6 Hardwoods } & 77 & 80 & 85.69 \\ \text { 1 Loblolly pine } & 49 & 80 & 88.58 \\ \text { 1 Loblolly pine } & 51 & 100 & 201.95 \\ \text { 1 Loblolly pine } & 41 & 80 & 146.48 \\ \text { 1 Loblolly pine } & 45 & 90 & 120.25 \\ \text { 1 Loblolly pine } & 46 & 90 & 75.00 \\ \text { 6 Hardwoods } & 70 & 80 & 104.29 \\ \text { 1 Loblolly pine } & 50 & 110 & 127.52 \\ \text { 6 Hardwoods } & 51 & 60 & 63.45 \\ \text { 1 Loblolly pine } & 42 & 80 & 18.87 \\ \text { 3 Slash pine } & 44 & 90 & 110.33 \\ \text { 6 Hardwoods } & 71 & 110 & 163.30 \\ \text { 5 Hdwd-pine mix } & 62 & 90 & 111.64 \\ \text { 1 Loblolly pine } & 47 & 90 & 68.56 \\ \text { 1 Loblolly pine } & 46 & 90 & 62.95 \\ \text { 1 Loblolly pine } & 46 & 90 & 135.33 \\ \text { 1 Loblolly pine } & 46 & 100 & 122.08 \\ \text { 1 Loblolly pine } & 14 & 90 & 89.98 \\ \text { 1 Loblolly pine } & 75 & 80 & 91.01 \\ \text { 6 Hardwoods } & 68 & 100 & 180.19 \\ \text { 6 Hardwoods } & 67 & 60 & 127.59 \\ \text { 2 Longleaf pine } & 32 & 70 & 106.70 \\ \text { 1 Loblolly pine } & 9 & 80 & 35.22 \\ \text { 5 Hdwd-pine mix } & 59 & 90 & 98.19 \\ \text { 1 Loblolly pine } & 14 & 85 & 181.62 \\ \text { 1 Loblolly pine } & 46 & 80 & 103.93 \\ \text { 6 Hardwoods } & 75 & 90 & 118.56 \\ \text { 2 Longleaf pine } & 46 & 80 & 73.13 \\ \text { 3 Slash pine } & 31 & 70 & 96.96 \\ \text { 6 Hardwoods } & 47 & 90 & 112.50 \\ \text { 6 Hardwoods } & 64 & 80 & 105.08 \\ & & & \\ & & & \\ & \end{array}$


DE- AI09-00SR22188 TECHNICAL REPORT

$\begin{array}{rrrr}51 & 100.28 & 0.00489 & 0.078 \\ 48.5 & 83.71 & 0.00268 & 0.043 \\ 38 & 85.27 & 0.00175 & 0.028 \\ 27 & 104.13 & 0.00095 & 0.015 \\ 2 & 30.00 & 0.00248 & 0.040 \\ 19 & 56.60 & 0.00194 & 0.031 \\ 56 & 102.70 & 0.00440 & 0.071 \\ 20 & 78.06 & 0.00299 & 0.048 \\ 61.5 & 93.67 & 0.00289 & 0.046 \\ 48.5 & 106.63 & 0.00151 & 0.024 \\ 46 & 99.42 & 0.00280 & 0.045 \\ 40 & 83.57 & 0.00767 & 0.123 \\ 38 & 91.69 & 0.00365 & 0.059 \\ 31 & 55.72 & 0.00570 & 0.091 \\ 29.5 & 50.00 & 0.00571 & 0.091 \\ 55 & 84.93 & 0.00556 & 0.089 \\ 51 & 82.36 & 0.00457 & 0.073 \\ 13 & 36.92 & 0.00518 & 0.083 \\ 35 & 57.44 & 0.00711 & 0.114 \\ 38 & 81.29 & 0.00239 & 0.038 \\ 8 & 18.82 & 0.00305 & 0.049 \\ 37.5 & 69.57 & 0.00524 & 0.084 \\ 43 & 88.67 & 0.00245 & 0.039 \\ 49.5 & 110.67 & 0.00147 & 0.024 \\ 17 & 81.00 & 0.00239 & 0.038 \\ 31 & 80.33 & 0.00331 & 0.053 \\ 38.5 & 85.31 & 0.00280 & 0.045 \\ 21 & 60.86 & 0.00207 & 0.033 \\ 41 & 72.00 & 0.00424 & 0.068 \\ 34 & 58.00 & 0.00316 & 0.051 \\ 9 & 29.80 & 0.00146 & 0.023 \\ 15 & 37.08 & 0.00533 & 0.085\end{array}$

2007

07-16-R

$\begin{array}{lrrr}\text { 7 Cypress-Tupelo } & 78 & 110 & 337.50 \\ \text { 1 Loblolly pine } & 50 & 90 & 76.35 \\ \text { 1 Loblolly pine } & 33 & 100 & 108.41 \\ \text { 6 Hardwoods } & 61 & 100 & 126.40 \\ \text { 1 Loblolly pine } & 8 & 90 & 49.17 \\ \text { 1 Loblolly pine } & 34 & 70 & 53.84 \\ \text { 7 Cypress-Tupelo } & 110 & 90 & 322.50 \\ \text { 5 Hdwd-pine mix } & 37 & 90 & 161.93 \\ \text { 3 Slash pine } & 44 & 90 & 69.17 \\ \text { 6 Hardwoods } & 85 & 90 & 94.52 \\ \text { 6 Hardwoods } & 62 & 100 & 125.36 \\ \text { 3 Slash pine } & 54 & 80 & 104.10 \\ \text { 1 Loblolly pine } & 34 & 100 & 166.35 \\ \text { 1 Loblolly pine } & 20 & 80 & 159.90 \\ \text { 1 Loblolly pine } & 20 & 80 & 116.82 \\ \text { 2 Longleaf pine } & 47 & 90 & 123.35 \\ \text { 1 Loblolly pine } & 58 & 80 & 160.69 \\ \text { 1 Loblolly pine } & 10 & 90 & 86.58 \\ \text { 2 Longleaf pine } & 34 & 70 & 117.76 \\ \text { 2 Longleaf pine } & 41 & 80 & 82.50 \\ \text { 1 Loblolly pine } & 12 & 80 & 33.00 \\ \text { 1 Loblolly pine } & 27 & 80 & 174.16 \\ \text { 6 Hardwoods } & 57 & 90 & 179.22 \\ \text { 6 Hardwoods } & 65 & 110 & 193.82 \\ \text { 1 Loblolly pine } & 43 & 90 & 114.87 \\ \text { 5 Hdwd-pine mix } & 57 & 90 & 116.36 \\ \text { 1 Loblolly pine } & 66 & 80 & 147.26 \\ \text { 2 Longleaf pine } & 52 & 60 & 71.98 \\ \text { 2 Longleaf pine } & 35 & 90 & 100.25 \\ \text { 3 Slash pine } & 54 & 60 & 63.56 \\ \text { 2 Longleaf pine } & 10 & 80 & 31.47 \\ \text { 1 Loblolly pine } & 10 & 80 & 87.72\end{array}$




\section{DE- AI09-00SR22188 TECHNICAL REPORT}

$\begin{array}{ll}4001 & 0.2691 \\ 4002 & 0.7409 \\ 4003 & 0.9805 \\ 4004 & 0.8236 \\ 4005 & 0.2801 \\ 4006 & 0.8546 \\ 4007 & 0.6289 \\ 4008 & 0.7869 \\ 4009 & 0.8751 \\ 4010 & 0.4140 \\ 4011 & 0.6814 \\ 4012 & 0.3478 \\ 4013 & 0.4597 \\ 4014 & 0.6568 \\ 4015 & 0.4185 \\ 4016 & 0.6490 \\ 4017 & 0.7480 \\ 4018 & 0.9216 \\ 4019 & 0.9044 \\ 4020 & 0.9417 \\ 4021 & 0.9742 \\ 4022 & 0.9434 \\ 4023 & 0.9768 \\ 4026 & 0.5894 \\ 4027 & 0.5917 \\ 4028 & 0.6921 \\ 4029 & 0.6510 \\ 4030 & 0.5872 \\ 4031 & 0.7685 \\ 4032 & 0.9833 \\ 4033 & 0.9323 \\ 4034 & 0.8748\end{array}$

$\begin{array}{rlll}27 & 63.75 & 0.00147 & 0.024 \\ 12 & 45.71 & 0.00220 & 0.035 \\ 12 & 41.20 & 0.00434 & 0.069 \\ 12 & 34.67 & 0.00332 & 0.053 \\ 12.5 & 59.50 & 0.00105 & 0.017 \\ 34 & 66.83 & 0.00354 & 0.057 \\ 16.5 & 62.17 & 0.00375 & 0.060 \\ 12.5 & 36.14 & 0.00250 & 0.040 \\ 43.5 & 72.40 & 0.00602 & 0.096 \\ 33 & 90.57 & 0.00416 & 0.067 \\ 11 & 46.00 & 0.00493 & 0.079 \\ 21 & 56.00 & 0.00126 & 0.020 \\ 18 & 63.86 & 0.00340 & 0.054 \\ 39 & 78.27 & 0.00275 & 0.044 \\ 37.5 & 68.57 & 0.00228 & 0.037 \\ 42 & 68.73 & 0.00446 & 0.071 \\ 46 & 73.62 & 0.00542 & 0.087 \\ 52 & 81.31 & 0.00484 & 0.078 \\ 21 & 45.41 & 0.00640 & 0.103 \\ 40 & 80.50 & 0.00628 & 0.101 \\ 14.5 & 38.20 & 0.00569 & 0.091 \\ 15 & 39.73 & 0.00476 & 0.076 \\ 10 & 32.36 & 0.00538 & 0.086 \\ 47 & 87.60 & 0.00152 & 0.024 \\ 30 & 78.50 & 0.00273 & 0.044 \\ 44 & 80.55 & 0.00436 & 0.070 \\ 47 & 85.45 & 0.00183 & 0.029 \\ 48.5 & 83.10 & 0.00180 & 0.029 \\ 46 & 88.27 & 0.00246 & 0.039 \\ 30.5 & 72.07 & 0.00251 & 0.040 \\ 10 & 34.00 & 0.00457 & 0.073 \\ 32.5 & 89.36 & 0.00268 & 0.043\end{array}$

$\begin{array}{lrrr}\text { 2 Longleaf pine } & 48 & 70 & 53.34 \\ \text { 2 Longleaf pine } & 47 & 60 & 67.54 \\ \text { 1 Loblolly pine } & 36 & 70 & 92.60 \\ \text { 6 Hardwoods } & 49 & 50 & 71.80 \\ \text { 6 Hardwoods } & 61 & 50 & 48.17 \\ \text { 1 Loblolly pine } & 46 & 80 & 120.08 \\ \text { 6 Hardwoods } & 46 & 70 & 87.72 \\ \text { 6 Hardwoods } & 35 & 60 & 51.39 \\ \text { 2 Longleaf pine } & 40 & 80 & 129.90 \\ \text { 1 Loblolly pine } & 46 & 80 & 119.28 \\ \text { 6 Hardwoods } & 41 & 60 & 93.75 \\ \text { 2 Longleaf pine } & 43 & 60 & 44.06 \\ \text { 5 Hdwd-pine mix } & 57 & 60 & 113.14 \\ \text { 2 Longleaf pine } & 41 & 80 & 90.00 \\ \text { 2 Longleaf pine } & 36 & 80 & 55.85 \\ \text { 2 Longleaf pine } & 34 & 80 & 91.58 \\ \text { 2 Longleaf pine } & 35 & 80 & 109.48 \\ \text { 1 Loblolly pine } & 44 & 80 & 155.55 \\ \text { 1 Loblolly pine } & 14 & 80 & 130.29 \\ \text { 3 Slash pine } & 42 & 80 & 178.75 \\ \text { 1 Loblolly pine } & 11 & 70 & 105.47 \\ \text { 1 Loblolly pine } & 15 & 70 & 94.33 \\ \text { 1 Loblolly pine } & 14 & 70 & 85.76 \\ \text { 1 Loblolly pine } & 48 & 90 & 82.50 \\ \text { 4 Pine-hdwd mix } & 37 & 90 & 99.28 \\ \text { 3 Slash pine } & 41 & 80 & 95.27 \\ \text { 1 Loblolly pine } & 46 & 90 & 92.41 \\ \text { 1 Loblolly pine } & 42 & 80 & 81.98 \\ \text { 1 Loblolly pine } & 45 & 90 & 91.06 \\ \text { 6 Hardwoods } & 64 & 80 & 139.78 \\ \text { 1 Loblolly pine } & 14 & 60 & 84.31 \\ \text { 6 Hardwoods } & 72 & 90 & 145.08\end{array}$




\section{DE- AI09-00SR22188 TECHNICAL REPORT}

\begin{tabular}{|c|c|c|c|c|c|}
\hline 4035 & 0.6891 & 29 & 78.22 & 0.00273 & 0.044 \\
\hline 4036 & 0.4698 & 28 & 79.00 & 0.00165 & 0.026 \\
\hline 4037 & 0.1915 & 10 & 73.67 & 0.00140 & 0.022 \\
\hline 4038 & 0.6579 & 11 & 29.83 & 0.00245 & 0.039 \\
\hline 4039 & 0.9969 & 52 & 81.71 & 0.00374 & 0.060 \\
\hline 4040 & 0.6993 & 45 & 82.83 & 0.00202 & 0.032 \\
\hline 4041 & 0.9040 & 12 & 31.38 & 0.00354 & 0.057 \\
\hline 4042 & 0.3494 & 53.5 & 87.67 & 0.00093 & 0.015 \\
\hline 4043 & 0.6616 & 42 & 83.36 & 0.00258 & 0.041 \\
\hline 4044 & 0.2889 & 10 & 62.00 & 0.00177 & 0.028 \\
\hline 4045 & 0.8754 & 34 & 73.08 & 0.00508 & 0.081 \\
\hline 4046 & 0.5488 & 28 & 72.57 & 0.00235 & 0.038 \\
\hline 4048 & 0.9221 & 44.5 & 87.13 & 0.00322 & 0.052 \\
\hline 4049 & 0.4940 & 42.5 & 80.50 & 0.00273 & 0.044 \\
\hline 4050 & 0.7927 & 49 & 82.69 & 0.00262 & 0.042 \\
\hline 4051 & 0.9242 & 31 & 57.81 & 0.00497 & 0.080 \\
\hline 4052 & 0.9717 & 18 & 56.60 & 0.00391 & 0.063 \\
\hline 4053 & 0.8532 & 30.5 & 56.25 & 0.00356 & 0.057 \\
\hline 4054 & 0.9043 & 23.5 & 52.07 & 0.00389 & 0.062 \\
\hline 4055 & 0.4593 & 38 & 77.25 & 0.00231 & 0.037 \\
\hline 4056 & 0.6744 & 40 & 64.91 & 0.00337 & 0.054 \\
\hline 4057 & 0.9519 & 39 & 71.29 & 0.00385 & 0.062 \\
\hline 4058 & 0.4281 & 21 & 56.83 & 0.00140 & 0.022 \\
\hline 4059 & 0.3297 & 9 & 79.60 & 0.00074 & 0.012 \\
\hline 4060 & 0.0584 & 42 & 72.00 & 0.00018 & 0.003 \\
\hline 4061 & 0.3085 & 21 & 80.75 & 0.00126 & 0.020 \\
\hline 4062 & 0.9445 & 45 & 85.47 & 0.00624 & 0.100 \\
\hline 4063 & 0.5809 & 36.5 & 70.89 & 0.00236 & 0.038 \\
\hline 4064 & 0.7279 & 47 & 84.15 & 0.00397 & 0.064 \\
\hline 4066 & 0.9899 & 13 & 33.85 & 0.00589 & 0.094 \\
\hline 4067 & 0.6973 & 24 & 69.43 & 0.00144 & 0.023 \\
\hline 4069 & 0.6992 & 21.5 & 54.80 & 0.00198 & 0.032 \\
\hline
\end{tabular}




\section{DE- AI09-00SR22188 TECHNICAL REPORT}

$\begin{array}{ll}4070 & 0.6839 \\ 4071 & 0.6419 \\ 4073 & 0.6675 \\ 4076 & 0.9920 \\ 4077 & 0.6974 \\ 4078 & 0.9390 \\ 4079 & 0.9406 \\ 4080 & 0.9192 \\ 4081 & 0.3485 \\ 4082 & 0.7088 \\ 4083 & 0.7938 \\ 4084 & 0.9834 \\ 4085 & 0.7834 \\ 4086 & 0.7851 \\ 4088 & 0.5963 \\ 4089 & 0.5445 \\ 4091 & 0.9394 \\ 4092 & 0.9823 \\ 4093 & 0.6294 \\ 4094 & 0.5862 \\ 4095 & 0.9263 \\ 4096 & 0.6549 \\ 4097 & 0.6562 \\ 4098 & 0.6270 \\ 4099 & 0.4251 \\ 4100 & 0.6307 \\ 4101 & 0.1788 \\ 4102 & 0.9959 \\ 4103 & 0.9795 \\ 4104 & 0.6115 \\ 4105 & 0.9124 \\ 4106 & 0.3759\end{array}$

$\begin{array}{rrrr}29 & 72.82 & 0.00228 & 0.037 \\ 10 & 25.33 & 0.00193 & 0.031 \\ 41 & 78.00 & 0.00484 & 0.078 \\ 11 & 34.90 & 0.00479 & 0.077 \\ 50 & 79.82 & 0.00511 & 0.082 \\ 25 & 56.44 & 0.00456 & 0.073 \\ 36.5 & 80.00 & 0.00329 & 0.053 \\ 12 & 33.82 & 0.00534 & 0.085 \\ 28 & 82.00 & 0.00213 & 0.034 \\ 17.5 & 61.75 & 0.00188 & 0.030 \\ 8 & 26.83 & 0.00176 & 0.028 \\ 10 & 24.82 & 0.00339 & 0.054 \\ 3 & 19.67 & 0.00110 & 0.018 \\ 34 & 59.13 & 0.00411 & 0.066 \\ 35.5 & 85.60 & 0.00590 & 0.094 \\ 11 & 81.56 & 0.00278 & 0.045 \\ 52 & 94.29 & 0.00472 & 0.076 \\ 41 & 82.93 & 0.00369 & 0.059 \\ 3.5 & 14.75 & 0.00161 & 0.026 \\ 28 & 82.89 & 0.00154 & 0.025 \\ 20.5 & 42.82 & 0.00701 & 0.112 \\ 53 & 84.64 & 0.00243 & 0.039 \\ 41.5 & 81.09 & 0.00430 & 0.069 \\ 16 & 60.00 & 0.00274 & 0.044 \\ 45.5 & 83.29 & 0.00373 & 0.060 \\ 29 & 63.80 & 0.00306 & 0.049 \\ 1 & 9.33 & 0.00024 & 0.004 \\ 17 & 41.50 & 0.00516 & 0.083 \\ 17 & 53.50 & 0.00742 & 0.119 \\ 19 & 79.86 & 0.00213 & 0.034 \\ 33 & 75.15 & 0.00934 & 0.150 \\ 44 & 75.50 & 0.00139 & 0.022\end{array}$

$\begin{array}{lrrr}\text { 2 Longleaf pine } & 40 & 90 & 94.62 \\ \text { 2 Longleaf pine } & 10 & 70 & 33.55 \\ \text { 3 Slash pine } & 41 & 80 & 99.72 \\ \text { 1 Loblolly pine } & 12 & 90 & 77.31 \\ \text { 3 Slash pine } & 44 & 90 & 97.50 \\ \text { 1 Loblolly pine } & 28 & 80 & 148.25 \\ \text { 1 Loblolly pine } & 31 & 90 & 156.78 \\ \text { 1 Loblolly pine } & 13 & 70 & 79.18 \\ \text { 3 Slash pine } & 45 & 80 & 72.05 \\ \text { 6 Hardwoods } & 49 & 60 & 100.51 \\ \text { 2 Longleaf pine } & 16 & 80 & 36.92 \\ \text { 2 Longleaf pine } & 15 & 60 & 56.13 \\ \text { 4 Pine-hdwd mix } & 38 & 70 & 20.53 \\ \text { 2 Longleaf pine } & 41 & 90 & 87.46 \\ \text { 3 Slash pine } & 41 & 90 & 147.99 \\ \text { 3 Slash pine } & 41 & 80 & 116.79 \\ \text { 1 Loblolly pine } & 45 & 90 & 158.05 \\ \text { 1 Loblolly pine } & 44 & 80 & 149.03 \\ \text { 2 Longleaf pine } & 10 & 80 & 14.60 \\ \text { 2 Longleaf pine } & 76 & 70 & 87.21 \\ \text { 1 Loblolly pine } & 20 & 70 & 141.10 \\ \text { 1 Loblolly pine } & 51 & 80 & 95.24 \\ \text { 3 Slash pine } & 54 & 80 & 104.71 \\ \text { 6 Hardwoods } & 55 & 60 & 90.19 \\ \text { 3 Slash pine } & 40 & 80 & 95.92 \\ \text { 2 Longleaf pine } & 46 & 70 & 94.73 \\ \text { 1 Loblolly pine } & 3 & 90 & 0.98 \\ \text { 1 Loblolly pine } & 12 & 80 & 99.33 \\ \text { 6 Hardwoods } & 27 & 80 & 87.31 \\ \text { 6 Hardwoods } & 30 & 100 & 96.84 \\ \text { 6 Hardwoods } & 30 & 90 & 154.94 \\ \text { 1 Loblolly pine } & 47 & 80 & 58.13 \\ & & & \end{array}$




\section{DE- AI09-00SR22188 TECHNICAL REPORT}

$\begin{array}{ll}4107 & 0.5256 \\ 4109 & 0.6867 \\ 4110 & 0.9989 \\ 4111 & 0.5806 \\ 4112 & 0.4011 \\ 4113 & 0.6358 \\ 4115 & 0.9100 \\ 4116 & 0.6733 \\ 4117 & 0.9877 \\ 4118 & 0.2911 \\ 4119 & 0.7135 \\ 4122 & 0.9078 \\ 4123 & 0.7727 \\ 4124 & 0.9172 \\ 4125 & 0.6825 \\ 4128 & 0.7771 \\ 4130 & 0.3727 \\ 4131 & 0.7244 \\ 4132 & 0.2778 \\ 4135 & 0.6147 \\ 4136 & 0.2211 \\ 4137 & 0.5789 \\ 4138 & 0.7087 \\ 4139 & 0.7247 \\ 4140 & 0.9920 \\ 4141 & 0.9317 \\ 4142 & 0.4028 \\ 4143 & 0.9299 \\ 4144 & 0.9995 \\ 4147 & 0.7306 \\ 4148 & 0.6904 \\ 4151 & 0.6743\end{array}$

$\begin{array}{rlll}36 & 78.63 & 0.00179 & 0.029 \\ 3 & 12.78 & 0.00075 & 0.012 \\ 4 & 21.78 & 0.00229 & 0.037 \\ 26 & 83.50 & 0.00387 & 0.062 \\ 57 & 91.43 & 0.00133 & 0.021 \\ 49.5 & 83.50 & 0.00396 & 0.063 \\ 14 & 39.73 & 0.00522 & 0.084 \\ 37 & 72.78 & 0.00506 & 0.081 \\ 13 & 35.27 & 0.00582 & 0.093 \\ 30 & 72.40 & 0.00170 & 0.027 \\ 17 & 64.86 & 0.00209 & 0.034 \\ 5 & 16.10 & 0.00554 & 0.089 \\ 54 & 91.31 & 0.00553 & 0.089 \\ 22 & 49.11 & 0.00621 & 0.099 \\ 46 & 78.18 & 0.00409 & 0.066 \\ 21.5 & 61.71 & 0.00244 & 0.039 \\ 28 & 71.50 & 0.00137 & 0.022 \\ 6 & 21.25 & 0.00220 & 0.035 \\ 3 & 10.90 & 0.00124 & 0.020 \\ 59 & 89.45 & 0.00190 & 0.030 \\ 3 & 10.00 & 0.00070 & 0.011 \\ 1.5 & 10.88 & 0.00130 & 0.021 \\ 46 & 80.27 & 0.00469 & 0.075 \\ 66 & 95.46 & 0.00230 & 0.037 \\ 4 & 13.81 & 0.00304 & 0.049 \\ 53 & 84.27 & 0.00629 & 0.101 \\ 33.5 & 56.83 & 0.00175 & 0.028 \\ 5 & 19.17 & 0.00201 & 0.032 \\ 15.5 & 44.86 & 0.00558 & 0.089 \\ 48 & 93.67 & 0.00316 & 0.051 \\ 26 & 80.18 & 0.00277 & 0.044 \\ 18.5 & 83.09 & 0.00164 & 0.026\end{array}$

$\begin{array}{lrrr}\text { 1 Loblolly pine } & 31 & 90 & 85.47 \\ \text { 2 Longleaf pine } & 8 & 70 & 11.72 \\ \text { 1 Loblolly pine } & 10 & 70 & 25.77 \\ \text { 4 Pine-hdwd mix } & 51 & 80 & 108.56 \\ \text { 1 Loblolly pine } & 44 & 90 & 58.20 \\ \text { 2 Longleaf pine } & 51 & 80 & 99.98 \\ \text { 6 Hardwoods } & 43 & 70 & 93.75 \\ \text { 2 Longleaf pine } & 49 & 80 & 102.74 \\ \text { 1 Loblolly pine } & 12 & 80 & 95.83 \\ \text { 1 Loblolly pine } & 52 & 70 & 82.97 \\ \text { 4 Pine-hdwd mix } & 25 & 80 & 74.60 \\ \text { 1 Loblolly pine } & 9 & 100 & 41.27 \\ \text { 3 Slash pine } & 44 & 90 & 135.00 \\ \text { 1 Loblolly pine } & 17 & 80 & 147.73 \\ \text { 3 Slash pine } & 43 & 90 & 95.24 \\ \text { 6 Hardwoods } & 60 & 60 & 70.85 \\ \text { 2 Longleaf pine } & 50 & 80 & 52.54 \\ \text { 4 Pine-hdwd mix } & 12 & 80 & 31.70 \\ \text { 3 Slash pine } & 4 & 80 & 7.39 \\ \text { 1 Loblolly pine } & 47 & 90 & 92.95 \\ \text { 1 Loblolly pine } & 5 & 80 & 3.04 \\ \text { 1 Loblolly pine } & 4 & 80 & 6.64 \\ \text { 3 Slash pine } & 44 & 80 & 131.23 \\ \text { 1 Loblolly pine } & 56 & 90 & 112.18 \\ \text { 2 Longleaf pine } & 5 & 70 & 30.21 \\ \text { 3 Slash pine } & 44 & 80 & 139.19 \\ \text { 1 Loblolly pine } & 28 & 70 & 45.00 \\ \text { 2 Longleaf pine } & 12 & 80 & 35.73 \\ \text { 1 Loblolly pine } & 18 & 80 & 130.20 \\ \text { 1 Loblolly pine } & 51 & 100 & 126.72 \\ \text { 3 Slash pine } & 44 & 80 & 107.90 \\ \text { 1 Loblolly pine } & 35 & 100 & 134.33\end{array}$




\section{DE- AI09-00SR22188 TECHNICAL REPORT}

$\begin{array}{ll}4152 & 0.9248 \\ 4153 & 0.9660 \\ 4154 & 0.8084 \\ 4155 & 0.6695 \\ 4156 & 0.9463 \\ 4157 & 0.9712 \\ 4158 & 0.6102 \\ 4159 & 0.3030 \\ 4161 & 0.3940 \\ 4162 & 0.9234 \\ 4164 & 0.2398 \\ 4165 & 0.6429 \\ 4166 & 0.9130 \\ 4167 & 0.5730 \\ 4168 & 0.6851 \\ 4169 & 0.9267 \\ 4171 & 0.9508 \\ 4172 & 0.5211 \\ 4173 & 0.9670 \\ 4174 & 0.7422 \\ 4177 & 0.4194 \\ 4178 & 0.8257 \\ 4182 & 0.9810 \\ 4183 & 0.7590 \\ 4184 & 0.5828 \\ 4185 & 0.9966 \\ 4186 & 0.9872 \\ 4187 & 0.6747 \\ 4188 & 0.9305 \\ 4189 & 0.4441 \\ 4190 & 0.4333 \\ 4191 & 0.8250\end{array}$

$\begin{array}{rrrr}34 & 60.44 & 0.00498 & 0.080 \\ 31.5 & 57.28 & 0.00535 & 0.086 \\ 57 & 100.36 & 0.00212 & 0.034 \\ 46.5 & 77.45 & 0.00341 & 0.055 \\ 3 & 11.29 & 0.00368 & 0.059 \\ 18 & 35.94 & 0.00805 & 0.129 \\ 41 & 72.70 & 0.00281 & 0.045 \\ 22 & 80.80 & 0.00108 & 0.017 \\ 17 & 51.20 & 0.00229 & 0.037 \\ 21 & 65.91 & 0.00426 & 0.068 \\ 0 & 11.50 & 0.00001 & 0.000 \\ 49 & 78.64 & 0.00378 & 0.061 \\ 19.5 & 44.94 & 0.00559 & 0.090 \\ 19.5 & 62.50 & 0.00246 & 0.039 \\ 32.5 & 64.00 & 0.00292 & 0.047 \\ 12 & 38.08 & 0.00488 & 0.078 \\ 49.5 & 91.18 & 0.00390 & 0.062 \\ 33.5 & 82.38 & 0.00240 & 0.038 \\ 34.5 & 57.19 & 0.00496 & 0.079 \\ 38 & 75.08 & 0.00459 & 0.073 \\ 36 & 62.83 & 0.00376 & 0.060 \\ 48.5 & 83.50 & 0.00675 & 0.108 \\ 45 & 66.15 & 0.00557 & 0.089 \\ 36 & 89.67 & 0.00325 & 0.052 \\ 1 & 9.00 & 0.00039 & 0.006 \\ 16.5 & 38.38 & 0.00593 & 0.095 \\ 5 & 15.64 & 0.00310 & 0.050 \\ 8 & 38.00 & 0.00211 & 0.034 \\ 11.5 & 30.33 & 0.00451 & 0.072 \\ 33 & 74.00 & 0.00249 & 0.040 \\ 15 & 37.50 & 0.00279 & 0.045 \\ 36 & 85.62 & 0.00527 & 0.084\end{array}$

\author{
1 Loblolly pine \\ 1 Loblolly pine \\ 1 Loblolly pine \\ 1 Loblolly pine \\ 1 Loblolly pine \\ 1 Loblolly pine \\ 1 Loblolly pine \\ 5 Hdwd-pine mix \\ 6 Hardwoods \\ 6 Hardwoods \\ 2 Longleaf pine \\ 3 Slash pine \\ 1 Loblolly pine \\ 6 Hardwoods \\ 1 Loblolly pine \\ 1 Loblolly pine \\ 6 Hardwoods \\ 1 Loblolly pine \\ 1 Loblolly pine \\ 3 Slash pine \\ 3 Slash pine \\ 1 Loblolly pine \\ 3 Slash pine \\ 1 Loblolly pine \\ 2 Longleaf pine \\ 1 Loblolly pine \\ 2 Longleaf pine \\ 1 Loblolly pine \\ 1 Loblolly pine \\ 1 Loblolly pine \\ 6 Hardwoods \\ 3 Slash pine
}

$\begin{array}{lll}20 & 90 & 142.67\end{array}$

$\begin{array}{lll}25 & 80 & 149.01\end{array}$

$\begin{array}{llll}49 & 100 & 132.72\end{array}$

$\begin{array}{llll}43 & 80 & 100.24\end{array}$

$\begin{array}{lll}6 & 80 & 19.57\end{array}$

$\begin{array}{lll}16 & 70 & 127.21\end{array}$

$\begin{array}{llll}40 & 80 & 85.84\end{array}$

$\begin{array}{lll}70 & 80 & 94.21\end{array}$

$\begin{array}{lll}43 & 60 & 51.89\end{array}$

$\begin{array}{llll}39 & 80 & 106.67\end{array}$

$\begin{array}{lll}8 & 100 & 0.88\end{array}$

$\begin{array}{lll}44 & 80 & 98.23\end{array}$

$\begin{array}{lll}16 & 90 & 135.03\end{array}$

$\begin{array}{lll}57 & 60 & 70.77\end{array}$

$\begin{array}{lll}23 & 90 & 102.36\end{array}$

$\begin{array}{lll}11 & 80 & 92.11\end{array}$

$\begin{array}{lll}59 & 90 & 187.98\end{array}$

$\begin{array}{lll}52 & 80 & 96.73\end{array}$

$\begin{array}{lll}19 & 90 & 129.51\end{array}$

$\begin{array}{lll}44 & 70 & 140.76\end{array}$

$\begin{array}{lll}44 & 70 & 75.48\end{array}$

$\begin{array}{lll}53 & 80 & 145.12\end{array}$

$\begin{array}{lll}50 & 90 & 94.59\end{array}$

$\begin{array}{lll}49 & 90 & 148.69\end{array}$

$\begin{array}{lll}8 & 80 & 5.57\end{array}$

$\begin{array}{lll}15 & 70 & 96.39\end{array}$

$\begin{array}{lll}6 & 80 & 31.18\end{array}$

$\begin{array}{lll}16 & 90 & 60.52\end{array}$

$\begin{array}{lll}12 & 80 & 68.48\end{array}$

$\begin{array}{lll}47 & 70 & 109.95\end{array}$

$\begin{array}{lll}0 & 90 & 15.79\end{array}$

$\begin{array}{lll}43 & 90 & 134.22\end{array}$ 
DE- AI09-00SR22188 TECHNICAL REPORT

$\begin{array}{rrrr}42 & 72.56 & 0.00646 & 0.104 \\ 27.5 & 72.55 & 0.01052 & 0.169 \\ 46.5 & 101.54 & 0.00643 & 0.103 \\ 28 & 85.13 & 0.00387 & 0.062 \\ 43 & 103.93 & 0.00282 & 0.045 \\ 14 & 36.33 & 0.00282 & 0.045 \\ 30.5 & 53.70 & 0.00342 & 0.055 \\ 49 & 82.07 & 0.00560 & 0.090 \\ 16 & 43.40 & 0.00421 & 0.067 \\ 9 & 30.40 & 0.00606 & 0.097 \\ 45.5 & 100.93 & 0.00311 & 0.050 \\ 36 & 71.33 & 0.00762 & 0.122 \\ 17.5 & 42.42 & 0.00741 & 0.119 \\ 16 & 84.00 & 0.00192 & 0.031 \\ 15 & 37.25 & 0.00591 & 0.095 \\ 21.5 & 75.56 & 0.00172 & 0.028 \\ 23 & 55.87 & 0.00389 & 0.062 \\ 50 & 78.86 & 0.00213 & 0.034 \\ 36.5 & 79.63 & 0.00248 & 0.040 \\ 52 & 86.57 & 0.00386 & 0.062 \\ 44.5 & 90.00 & 0.00585 & 0.094 \\ 42 & 93.50 & 0.00452 & 0.072 \\ 18 & 42.73 & 0.00511 & 0.082 \\ 27.5 & 54.95 & 0.00718 & 0.115 \\ 49.5 & 79.06 & 0.00418 & 0.067 \\ 49 & 90.48 & 0.00479 & 0.077 \\ 28 & 70.00 & 0.00449 & 0.072 \\ 59 & 98.92 & 0.00141 & 0.023 \\ 14 & 70.29 & 0.00324 & 0.052 \\ 34 & 97.38 & 0.00210 & 0.034 \\ 41 & 91.71 & 0.00302 & 0.048 \\ 14.5 & 57.00 & 0.00330 & 0.053\end{array}$

2007

07-16-R

$\begin{array}{lrrr}\text { 1 Loblolly pine } & 25 & 90 & 154.24 \\ \text { 6 Hardwoods } & 50 & 80 & 105.00 \\ \text { 4 Pine-hdwd mix } & 79 & 90 & 153.28 \\ \text { 5 Hdwd-pine mix } & 62 & 90 & 87.30 \\ \text { 6 Hardwoods } & 57 & 100 & 152.22 \\ \text { 1 Loblolly pine } & 12 & 80 & 49.10 \\ \text { 1 Loblolly pine } & 24 & 80 & 88.32 \\ \text { 3 Slash pine } & 38 & 90 & 149.98 \\ \text { 1 Loblolly pine } & 43 & 60 & 106.36 \\ \text { 1 Loblolly pine } & 12 & 70 & 77.99 \\ \text { 1 Loblolly pine } & 60 & 100 & 165.74 \\ \text { 6 Hardwoods } & 48 & 90 & 93.32 \\ \text { 1 Loblolly pine } & 15 & 70 & 152.22 \\ \text { 5 Hdwd-pine mix } & 55 & 80 & 90.56 \\ \text { 1 Loblolly pine } & 15 & 80 & 101.48 \\ \text { 4 Pine-hdwd mix } & 43 & 80 & 76.91 \\ \text { 1 Loblolly pine } & 21 & 80 & 130.44 \\ \text { 1 Loblolly pine } & 42 & 80 & 56.98 \\ \text { 6 Hardwoods } & 44 & 80 & 73.04 \\ \text { 1 Loblolly pine } & 52 & 80 & 137.66 \\ \text { 4 Pine-hdwd mix } & 70 & 90 & 118.89 \\ \text { 1 Loblolly pine } & 49 & 90 & 172.50 \\ \text { 1 Loblolly pine } & 12 & 80 & 97.20 \\ \text { 1 Loblolly pine } & 24 & 80 & 184.35 \\ \text { 1 Loblolly pine } & 24 & 100 & 173.35 \\ \text { 7 Cypress-Tupelo } & 75 & 90 & 234.61 \\ \text { 1 Loblolly pine } & 40 & 80 & 115.55 \\ \text { 1 Loblolly pine } & 53 & 90 & 94.73 \\ \text { 6 Hardwoods } & 53 & 70 & 89.30 \\ \text { 5 Hdwd-pine mix } & 88 & 90 & 98.04 \\ \text { 4 Pine-hdwd mix } & 59 & 90 & 103.51 \\ \text { 6 Hardwoods } & 35 & 80 & 49.06\end{array}$




\section{DE- AI09-00SR22188 TECHNICAL REPORT}

$\begin{array}{ll}4232 & 0.9528 \\ 4234 & 0.8680 \\ 4235 & 0.9514 \\ 4236 & 0.8546 \\ 4237 & 0.4855 \\ 4239 & 0.2042 \\ 4240 & 0.9813 \\ 4243 & 0.7671 \\ 4244 & 0.7202 \\ 4245 & 0.6527 \\ 4246 & 0.9773 \\ 4247 & 0.8196 \\ 4248 & 0.5502 \\ 4249 & 0.6975 \\ 4250 & 0.7890 \\ 4252 & 0.9904 \\ 4254 & 0.9006 \\ 4255 & 0.8865 \\ 4259 & 0.9901 \\ 4260 & 0.9048 \\ 4261 & 0.4865 \\ 4263 & 0.9625 \\ 4264 & 0.6516 \\ 4265 & 0.7578 \\ 4268 & 0.3715 \\ 4269 & 0.4528 \\ 4273 & 0.5744 \\ 4274 & 0.7856 \\ 4275 & 0.7367 \\ 4276 & 0.3636 \\ 4277 & 0.9959 \\ 4278 & 0.3734\end{array}$

$\begin{array}{rrrr}26 & 54.53 & 0.00562 & 0.090 \\ 4 & 13.86 & 0.00412 & 0.066 \\ 11 & 36.33 & 0.00402 & 0.064 \\ 40.5 & 80.64 & 0.00821 & 0.132 \\ 7 & 68.29 & 0.00105 & 0.017 \\ 25 & 60.00 & 0.00112 & 0.018 \\ 38 & 63.60 & 0.00415 & 0.066 \\ 44 & 91.50 & 0.00353 & 0.057 \\ 39 & 62.73 & 0.00303 & 0.048 \\ 54 & 85.09 & 0.00640 & 0.102 \\ 11 & 41.09 & 0.00423 & 0.068 \\ 55 & 96.21 & 0.00213 & 0.034 \\ 44.5 & 82.78 & 0.00495 & 0.079 \\ 26 & 74.00 & 0.00168 & 0.027 \\ 16.5 & 42.63 & 0.00406 & 0.065 \\ 16 & 36.83 & 0.00534 & 0.086 \\ 17 & 43.38 & 0.00722 & 0.116 \\ 41 & 94.77 & 0.00181 & 0.029 \\ 13 & 36.58 & 0.00595 & 0.095 \\ 28 & 59.41 & 0.00617 & 0.099 \\ 21.5 & 86.13 & 0.00262 & 0.042 \\ 38 & 65.13 & 0.00437 & 0.070 \\ 27 & 79.33 & 0.00769 & 0.123 \\ 50 & 88.08 & 0.00563 & 0.090 \\ 42.5 & 78.67 & 0.00270 & 0.043 \\ 48 & 84.75 & 0.00377 & 0.060 \\ 63 & 100.20 & 0.00152 & 0.024 \\ 7 & 28.17 & 0.00398 & 0.064 \\ 51 & 88.00 & 0.00350 & 0.056 \\ 39 & 81.83 & 0.00275 & 0.044 \\ 16 & 40.73 & 0.00521 & 0.084 \\ 35 & 74.17 & 0.00163 & 0.026\end{array}$

\begin{tabular}{|c|c|c|c|}
\hline 1 Loblolly pine & 17 & 90 & 144.52 \\
\hline 1 Loblolly pine & 5 & 70 & 24.60 \\
\hline 1 Loblolly pine & 12 & 80 & 85.86 \\
\hline 5 Hdwd-pine mix & 57 & 80 & 112.90 \\
\hline 2 Longleaf pine & 45 & 70 & 62.98 \\
\hline 1 Loblolly pine & 22 & 80 & 37.32 \\
\hline 1 Loblolly pine & 23 & 90 & 129.37 \\
\hline 6 Hardwoods & 85 & 90 & 198.86 \\
\hline 1 Loblolly pine & 24 & 90 & 83.71 \\
\hline 3 Slash pine & 45 & 90 & 94.13 \\
\hline 1 Loblolly pine & 14 & 90 & 89.71 \\
\hline 1 Loblolly pine & 58 & 90 & 124.73 \\
\hline 3 Slash pine & 41 & 80 & 86.89 \\
\hline 6 Hardwoods & 39 & 80 & 75.59 \\
\hline 1 Loblolly pine & 13 & 70 & 84.61 \\
\hline 1 Loblolly pine & 12 & 90 & 82.90 \\
\hline 1 Loblolly pine & 19 & 80 & 149.72 \\
\hline 6 Hardwoods & 46 & 90 & 123.93 \\
\hline 1 Loblolly pine & 10 & 90 & 100.08 \\
\hline 1 Loblolly pine & 21 & 90 & 165.05 \\
\hline 3 Slash pine & 43 & 90 & 101.62 \\
\hline 1 Loblolly pine & 23 & 90 & 142.27 \\
\hline 2 Longleaf pine & 74 & 70 & 114.51 \\
\hline 3 Slash pine & 44 & 80 & 150.98 \\
\hline 3 Slash pine & 44 & 80 & 73.69 \\
\hline 3 Slash pine & 43 & 80 & 78.61 \\
\hline 1 Loblolly pine & 42 & 100 & 80.70 \\
\hline 1 Loblolly pine & 10 & 80 & 52.48 \\
\hline 1 Loblolly pine & 42 & 90 & 122.72 \\
\hline 1 Loblolly pine & 40 & 80 & 80.84 \\
\hline 1 Loblolly pine & 12 & 80 & 106.54 \\
\hline 2 Longleaf pine & 43 & 80 & 53.05 \\
\hline
\end{tabular}




\section{DE- AI09-00SR22188 TECHNICAL REPORT}

$\begin{array}{ll}4281 & 0.9315 \\ 4283 & 0.7227 \\ 4284 & 0.6707 \\ 4285 & 0.5091 \\ 4286 & 0.5968 \\ 4287 & 0.6243 \\ 4288 & 0.7498 \\ 4289 & 0.6521 \\ 4290 & 0.8391 \\ 4291 & 0.5343 \\ 4293 & 0.6234 \\ 4294 & 0.6278 \\ 4295 & 0.3213 \\ 4296 & 0.4838 \\ 4297 & 0.9090 \\ 4298 & 0.9025 \\ 4299 & 0.4088 \\ 4300 & 0.7916 \\ 4301 & 0.4093 \\ 4302 & 0.5078 \\ 4303 & 0.4980 \\ 4304 & 0.6295 \\ 4306 & 0.5111 \\ 4309 & 0.4666 \\ 4311 & 0.5044 \\ 4313 & 0.9514 \\ 4314 & 0.5529 \\ 4315 & 0.4504 \\ 4316 & 0.5140 \\ 4318 & 0.3958 \\ 4319 & 0.1802 \\ 4321 & 0.9934\end{array}$

$\begin{array}{rrrr}25.5 & 58.00 & 0.00432 & 0.069 \\ 57.5 & 86.54 & 0.00321 & 0.051 \\ 14 & 58.83 & 0.00134 & 0.021 \\ 41 & 83.63 & 0.00216 & 0.035 \\ 13.5 & 72.67 & 0.00193 & 0.031 \\ 25.5 & 67.20 & 0.00218 & 0.035 \\ 20 & 54.89 & 0.00283 & 0.045 \\ 52 & 79.75 & 0.00643 & 0.103 \\ 59 & 116.47 & 0.00378 & 0.061 \\ 40 & 89.00 & 0.00326 & 0.052 \\ 17 & 47.50 & 0.00358 & 0.057 \\ 46 & 80.55 & 0.00290 & 0.046 \\ 17 & 77.80 & 0.00156 & 0.025 \\ 8.5 & 83.00 & 0.00122 & 0.020 \\ 44 & 78.00 & 0.00752 & 0.121 \\ 37 & 60.93 & 0.00497 & 0.080 \\ 7.5 & 19.00 & 0.00130 & 0.021 \\ 51 & 100.36 & 0.00219 & 0.035 \\ 41 & 82.43 & 0.00148 & 0.024 \\ 50 & 85.33 & 0.00214 & 0.034 \\ 44 & 89.89 & 0.00212 & 0.034 \\ 49 & 93.27 & 0.00261 & 0.042 \\ 36 & 88.67 & 0.00234 & 0.038 \\ 37 & 101.88 & 0.00098 & 0.016 \\ 35.5 & 82.00 & 0.00496 & 0.079 \\ 52 & 83.50 & 0.00562 & 0.090 \\ 28 & 76.44 & 0.00345 & 0.055 \\ 18 & 50.83 & 0.00155 & 0.025 \\ 60 & 97.44 & 0.00178 & 0.028 \\ 49 & 79.00 & 0.00224 & 0.036 \\ 43.5 & 82.67 & 0.00151 & 0.024 \\ 28 & 45.53 & 0.00821 & 0.131\end{array}$

1 Loblolly pine
1 Loblolly pine
6 Hardwoods
3 Slash pine
6 Hardwoods
2 Longleaf pine
1 Loblolly pine
2 Longleaf pine
1 Loblolly pine
3 Slash pine
1 Loblolly pine
2 Longleaf pine
3 Slash pine
3 Slash pine
2 Longleaf pine
1 Loblolly pine
2 Longleaf pine
1 Loblolly pine
2 Longleaf pine
2 Longleaf pine
2 Longleaf pine
1 Loblolly pine
6 Hardwoods
1 Loblolly pine
3 Slash pine
1 Loblolly pine
3 Slash pine
1 Loblolly pine
1 Loblolly pine
2 Longleaf pine
Longleaf pine
Loblolly pine

$\begin{array}{lll}17 & 100 & 134.00\end{array}$

$\begin{array}{lll}51 & 90 & 128.02\end{array}$

$\begin{array}{lll}37 & 90 & 78.81\end{array}$

$\begin{array}{lll}45 & 90 & 73.75\end{array}$

$\begin{array}{lll}57 & 60 & 90.78\end{array}$

$\begin{array}{lll}56 & 60 & 93.17\end{array}$

$\begin{array}{lll}23 & 90 & 87.56\end{array}$

$\begin{array}{lll}52 & 80 & 127.50\end{array}$

$\begin{array}{lll}58 & 110 & 217.40\end{array}$

$\begin{array}{lll}45 & 90 & 131.02\end{array}$

$\begin{array}{lll}29 & 70 & 93.63\end{array}$

$\begin{array}{lll}44 & 80 & 82.50\end{array}$

$\begin{array}{lll}41 \quad 90 & 72.82\end{array}$

$\begin{array}{lll}42 & 90 & 93.34\end{array}$

$\begin{array}{lll}55 & 70 & 212.04\end{array}$

$\begin{array}{lll}16 \quad 80 & 139.73\end{array}$

$\begin{array}{lll}8 & 80 & 20.63\end{array}$

$\begin{array}{lll}62 & 90 & 140.57\end{array}$

$\begin{array}{lll}42 & 80 & 52.50\end{array}$

$\begin{array}{lll}47 \quad 80 & 75.04\end{array}$

$\begin{array}{lll}46 & 80 & 87.53\end{array}$

$\begin{array}{lll}45 & 100 & 136.41\end{array}$

$\begin{array}{lll}40 & 80 & 155.75\end{array}$

$\begin{array}{lll}47 & 100 & 83.11\end{array}$

$\begin{array}{lll}51 \quad 80 & 105.25\end{array}$

$\begin{array}{lll}49 \quad 80 & 177.08\end{array}$

$\begin{array}{lll}42 & 80 & 115.08\end{array}$

$\begin{array}{lll}20 & 70 & 52.89\end{array}$

$\begin{array}{lll}49 & 100 & 87.82\end{array}$

$\begin{array}{lll}41 \quad 90 & 52.50\end{array}$

$\begin{array}{lll}45 & 90 & 45.00\end{array}$

$\begin{array}{lll}17 \quad 80 & 178.35\end{array}$ 


\section{DE- AI09-00SR22188 TECHNICAL REPORT}

$\begin{array}{ll}4322 & 0.9106 \\ 4323 & 0.5142 \\ 4324 & 0.3626 \\ 4325 & 0.5195 \\ 4326 & 0.5226 \\ 4327 & 0.8759 \\ 4329 & 0.7230 \\ 4330 & 0.4337 \\ 4339 & 0.5778 \\ 4341 & 0.6149 \\ 4342 & 0.6504 \\ 4344 & 0.5540 \\ 4345 & 0.4584 \\ 4346 & 0.5882 \\ 4347 & 0.4649 \\ 4349 & 0.3887 \\ 4351 & 0.5605 \\ 4352 & 0.6717 \\ 4353 & 0.3434 \\ 4354 & 0.9173 \\ 4355 & 0.2519 \\ 4356 & 0.9467 \\ 4357 & 0.9398 \\ 4359 & 0.4078 \\ 4361 & 0.8185 \\ 4364 & 0.4388 \\ 4366 & 0.7623 \\ 4367 & 0.4857 \\ 4368 & 0.7757 \\ 4370 & 0.3435 \\ 4371 & 0.4394 \\ 4372 & 0.3066\end{array}$

$\begin{array}{rrrl}24 & 44.92 & 0.00536 & 0.086 \\ 21 & 90.00 & 0.00117 & 0.019 \\ 6 & 15.60 & 0.00105 & 0.017 \\ 53 & 84.11 & 0.00138 & 0.022 \\ 37 & 77.11 & 0.00232 & 0.037 \\ 25 & 78.50 & 0.00487 & 0.078 \\ 35.5 & 70.82 & 0.00692 & 0.111 \\ 5 & 27.83 & 0.00133 & 0.021 \\ 55 & 89.10 & 0.00600 & 0.096 \\ 45 & 82.60 & 0.00423 & 0.068 \\ 41.5 & 81.45 & 0.00459 & 0.074 \\ 48 & 82.60 & 0.00275 & 0.044 \\ 49 & 80.13 & 0.00286 & 0.046 \\ 9 & 37.00 & 0.00283 & 0.045 \\ 50.5 & 88.63 & 0.00294 & 0.047 \\ 48 & 81.57 & 0.00233 & 0.037 \\ 46 & 79.50 & 0.00246 & 0.039 \\ 51.5 & 85.08 & 0.00251 & 0.040 \\ 17 & 67.75 & 0.00128 & 0.021 \\ 50 & 79.44 & 0.00364 & 0.058 \\ 34 & 75.50 & 0.00099 & 0.016 \\ 11 & 32.36 & 0.00283 & 0.045 \\ 25 & 91.64 & 0.00493 & 0.079 \\ 35 & 110.67 & 0.00201 & 0.032 \\ 78 & 111.13 & 0.00215 & 0.034 \\ 53 & 83.13 & 0.00279 & 0.045 \\ 39.5 & 83.11 & 0.00851 & 0.136 \\ 57 & 80.50 & 0.00269 & 0.043 \\ 46 & 85.46 & 0.00238 & 0.038 \\ 37.5 & 79.83 & 0.00191 & 0.031 \\ 49 & 83.38 & 0.00261 & 0.042 \\ 15 & 69.33 & 0.00373 & 0.060\end{array}$

1 Loblolly pine
1 Loblolly pine
2 Longleaf pine
1 Loblolly pine
2 Longleaf pine
1 Loblolly pine
2 Longleaf pine
4 Pine-hdwd mix
3 Slash pine
5 Hdwd-pine mix
2 Longleaf pine
2 Longleaf pine
2 Longleaf pine
1 Loblolly pine
3 Slash pine
2 Longleaf pine
2 Longleaf pine
1 Loblolly pine
2 Longleaf pine
1 Loblolly pine
2 Longleaf pine
1 Loblolly pine
6 Hardwoods
6 Hardwoods
1 Loblolly pine
2 Longleaf pine
1 Loblolly pine
1 Loblolly pine
1 Loblolly pine
2 Longleaf pine
2 Longleaf pine
6 Hardwoods

$\begin{array}{lll}17 \quad 90 & 106.97\end{array}$

$\begin{array}{lll}44 & 90 & 100.71\end{array}$

$\begin{array}{lll}8 & 80 & 13.96\end{array}$

$\begin{array}{lll}42 & 90 & 67.50\end{array}$

$\begin{array}{lll}42 & 80 & 77.38\end{array}$

$\begin{array}{lll}59 & 80 & 126.04\end{array}$

$\begin{array}{lll}48 & 70 & 119.01\end{array}$

$\begin{array}{lll}3 & 80 & 20.48\end{array}$

$\begin{array}{lll}51 & 90 & 134.01\end{array}$

$\begin{array}{lll}48 & 90 & 106.21\end{array}$

$\begin{array}{lll}44 & 90 & 117.78\end{array}$

$\begin{array}{lll}41 \quad 90 & 75.00\end{array}$

$\begin{array}{lll}41 \quad 90 & 67.50\end{array}$

$\begin{array}{lll}11 & 70 & 72.10\end{array}$

$\begin{array}{lll}43 & 90 & 71.10\end{array}$

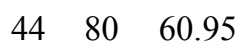

$\begin{array}{lll}50 & 80 & 75.00\end{array}$

$\begin{array}{lll}39 & 90 & 90.00\end{array}$

$\begin{array}{lll}88 & 50 & 48.48\end{array}$

$\begin{array}{lll}40 \quad 90 & 120.00\end{array}$

$44 \quad 80 \quad 35.89$

$\begin{array}{lll}14 & 70 & 59.97\end{array}$

$\begin{array}{lll}66 & 90 & 131.47\end{array}$

$\begin{array}{lll}75 & 90 & 84.23\end{array}$

$\begin{array}{lll}49 & 110 & 120.75\end{array}$

$\begin{array}{lll}43 \quad 80 & 60.00\end{array}$

$\begin{array}{lll}60 & 90 & 125.99\end{array}$

$\begin{array}{lll}45 & 90 & 69.98\end{array}$

$\begin{array}{lll}46 & 80 & 124.78\end{array}$

$\begin{array}{lll}41 \quad 80 & 61.29\end{array}$

$\begin{array}{lll}43 \quad 80 & 67.50\end{array}$

$\begin{array}{lll}63 & 60 & 67.55\end{array}$ 
DE- AI09-00SR22188

TECHNICAL REPORT

2007

07-16-R

\begin{tabular}{|c|c|c|c|c|}
\hline 7 & 24.89 & 0.00307 & 0.049 & 1 \\
\hline 39.5 & 76.22 & 0.00276 & 0.044 & 2 \\
\hline 22 & 49.00 & 0.00297 & 0.048 & 3 \\
\hline 45 & 92.00 & 0.00214 & 0.034 & 4 \\
\hline 31 & 79.57 & 0.00162 & 0.026 & 4 \\
\hline 6 & 53.80 & 0.00110 & 0.018 & 2 \\
\hline 13 & 102.07 & 0.00111 & 0.018 & 0 \\
\hline 35 & 100.85 & 0.00347 & 0.056 & 0 \\
\hline 51 & 89.71 & 0.00555 & 0.089 & 2 \\
\hline 41 & 89.88 & 0.00217 & 0.035 & 2 \\
\hline 41 & 95.13 & 0.00208 & 0.033 & 4 \\
\hline 59 & 97.33 & 0.00373 & 0.060 & 2 \\
\hline 47 & 84.83 & 0.00442 & 0.071 & 1 \\
\hline 67 & 120.69 & 0.00210 & 0.034 & 1 \\
\hline 50.5 & 80.70 & 0.00330 & 0.053 & 3 \\
\hline 17 & 48.90 & 0.00494 & 0.079 & 2 \\
\hline 40.5 & 65.58 & 0.00304 & 0.049 & 1 \\
\hline 17 & 44.20 & 0.00429 & 0.069 & 2 \\
\hline 9 & 25.86 & 0.00253 & 0.041 & 3 \\
\hline 7 & 19.91 & 0.00169 & 0.027 & 2 \\
\hline 6 & 25.80 & 0.00363 & 0.058 & 2 \\
\hline 15 & 40.90 & 0.00431 & 0.069 & 0 \\
\hline 29 & 87.86 & 0.00217 & 0.035 & 0 \\
\hline 21.5 & 54.40 & 0.00322 & 0.052 & 1 \\
\hline 43 & 94.20 & 0.00613 & 0.098 & 1 \\
\hline 26 & 83.22 & 0.00329 & 0.053 & 1 \\
\hline 30 & 94.43 & 0.00252 & 0.040 & 0 \\
\hline 42 & 79.00 & 0.00223 & 0.036 & 3 \\
\hline 41 & 98.71 & 0.00213 & 0.034 & 3 \\
\hline 55 & 90.38 & 0.00257 & 0.041 & 3 \\
\hline 46 & 88.62 & 0.00281 & 0.045 & 2 \\
\hline 25.5 & 63.17 & 0.00138 & 0.022 & 2 \\
\hline
\end{tabular}

$\begin{array}{lrrr}\text { 2 Longleaf pine } & 11 & 70 & 54.11 \\ \text { 2 Longleaf pine } & 40 & 80 & 84.90 \\ \text { 1 Loblolly pine } & 19 & 80 & 83.86 \\ \text { 4 Pine-hdwd mix } & 60 & 90 & 106.16 \\ \text { 1 Loblolly pine } & 40 & 90 & 84.01 \\ \text { 2 Longleaf pine } & 40 & 60 & 48.43 \\ \text { 1 Loblolly pine } & 42 & 110 & 131.42 \\ \text { 6 Hardwoods } & 95 & 90 & 145.47 \\ \text { 2 Longleaf pine } & 45 & 90 & 155.83 \\ \text { 1 Loblolly pine } & 100 & 95 & 102.98 \\ \text { 1 Loblolly pine } & 50 & 100 & 127.06 \\ \text { 3 Slash pine } & 51 & 90 & 103.10 \\ \text { 3 Slash pine } & 44 & 90 & 129.13 \\ \text { 1 Loblolly pine } & 71 & 110 & 148.86 \\ \text { 2 Longleaf pine } & 80 & 70 & 87.48 \\ \text { 1 Loblolly pine } & 22 & 70 & 110.23 \\ \text { 1 Loblolly pine } & 22 & 100 & 95.53 \\ \text { 1 Loblolly pine } & 12 & 60 & 108.24 \\ \text { 2 Longleaf pine } & 10 & 80 & 38.83 \\ \text { 2 Longleaf pine } & 10 & 80 & 39.05 \\ \text { 2 Longleaf pine } & 10 & 80 & 44.17 \\ \text { 1 Loblolly pine } & 12 & 70 & 83.87 \\ \text { 6 Hardwoods } & 56 & 70 & 99.89 \\ \text { 1 Loblolly pine } & 16 & 100 & 83.56 \\ \text { 6 Hardwoods } & 56 & 90 & 118.90 \\ \text { 6 Hardwoods } & 66 & 80 & 183.35 \\ \text { 6 Hardwoods } & 56 & 90 & 94.94 \\ \text { 2 Longleaf pine } & 42 & 90 & 67.50 \\ \text { 1 Loblolly pine } & 90 & 95 & 109.89 \\ \text { 1 Loblolly pine } & 48 & 98 & 130.12 \\ \text { 2 Longleaf pine } & 58 & 80 & 115.85 \\ \text { 4 Pine-hdwd mix } & 44 & 70 & 45.00 \\ & & & \\ \text { (n) } & & \end{array}$


DE- AI09-00SR22188 TECHNICAL REPORT

$\begin{array}{rrrr}20 & 45.06 & 0.00878 & 0.141 \\ 25.5 & 83.44 & 0.00256 & 0.041 \\ 29 & 75.25 & 0.00291 & 0.047 \\ 6 & 26.13 & 0.00302 & 0.048 \\ 16 & 67.17 & 0.00772 & 0.124 \\ 46.5 & 91.29 & 0.00132 & 0.021 \\ 19 & 52.78 & 0.00413 & 0.066 \\ 60 & 105.71 & 0.00475 & 0.076 \\ 35 & 109.71 & 0.00430 & 0.069 \\ 46.5 & 91.67 & 0.00404 & 0.065 \\ 28 & 67.00 & 0.00557 & 0.089 \\ 46 & 81.80 & 0.02152 & 0.345 \\ 45 & 86.08 & 0.00303 & 0.049 \\ 44 & 89.40 & 0.00104 & 0.017 \\ 43 & 112.50 & 0.00218 & 0.035 \\ 46 & 79.00 & 0.00290 & 0.046 \\ 45 & 100.00 & 0.00184 & 0.029 \\ 49 & 91.78 & 0.00495 & 0.079 \\ 39 & 89.00 & 0.00450 & 0.072 \\ 48.5 & 103.83 & 0.00386 & 0.062 \\ 27 & 83.00 & 0.00364 & 0.058 \\ 26.5 & 74.60 & 0.00170 & 0.027 \\ 49.5 & 80.20 & 0.00212 & 0.034 \\ 16 & 61.75 & 0.00239 & 0.038 \\ 20.5 & 50.50 & 0.00416 & 0.067 \\ 29.5 & 62.00 & 0.00258 & 0.041 \\ 50 & 86.33 & 0.00196 & 0.031 \\ 11 & 39.33 & 0.00626 & 0.100 \\ 13 & 82.86 & 0.00107 & 0.017 \\ 3 & 11.75 & 0.00236 & 0.038 \\ 16.5 & 68.75 & 0.00288 & 0.046 \\ 42 & 77.75 & 0.00181 & 0.029\end{array}$

2007

07-16-R

$\begin{array}{lrrr}\text { 1 Loblolly pine } & 15 & 80 & 136.98 \\ \text { 3 Slash pine } & 52 & 90 & 88.05 \\ \text { 6 Hardwoods } & 38 & 80 & 100.44 \\ \text { 2 Longleaf pine } & 80 & 80 & 61.47 \\ \text { 6 Hardwoods } & 64 & 80 & 165.27 \\ \text { 1 Loblolly pine } & 48 & 90 & 75.33 \\ \text { 6 Hardwoods } & 20 & 90 & 85.09 \\ \text { 7 Cypress-Tupelo } & 199 & 60 & 313.75 \\ \text { 6 Hardwoods } & 78 & 100 & 203.62 \\ \text { 5 Hdwd-pine mix } & 50 & 90 & 69.86 \\ \text { 1 Loblolly pine } & 42 & 80 & 112.62 \\ \text { 5 Hdwd-pine mix } & 42 & 90 & 127.50 \\ \text { 2 Longleaf pine } & 44 & 90 & 99.50 \\ \text { 2 Longleaf pine } & 43 & 90 & 37.50 \\ \text { 4 Pine-hdwd mix } & 80 & 110 & 157.20 \\ \text { 1 Loblolly pine } & 42 & 80 & 112.23 \\ \text { 1 Loblolly pine } & 46 & 100 & 119.24 \\ \text { 7 Cypress-Tupelo } & 80 & 80 & 290.37 \\ \text { 6 Hardwoods } & 57 & 80 & 124.59 \\ \text { 6 Hardwoods } & 67 & 95 & 138.16 \\ \text { 6 Hardwoods } & 38 & 90 & 111.86 \\ \text { 5 Hdwd-pine mix } & 42 & 80 & 38.05 \\ \text { 1 Loblolly pine } & 40 & 80 & 89.15 \\ \text { 1 Loblolly pine } & 23 & 80 & 90.69 \\ \text { 1 Loblolly pine } & 25 & 70 & 113.32 \\ \text { 6 Hardwoods } & 2 & 80 & 37.83 \\ \text { 1 Loblolly pine } & 40 & 90 & 93.03 \\ \text { 1 Loblolly pine } & 12 & 90 & 118.76 \\ \text { 3 Slash pine } & 44 & 80 & 62.72 \\ \text { 2 Longleaf pine } & 6 & 70 & 22.39 \\ \text { 1 Loblolly pine } & 47 & 70 & 83.27 \\ \text { 2 Longleaf pine } & 43 & 80 & 60.00\end{array}$


DE- AI09-00SR22188 TECHNICAL REPORT 2007 07-16-R

\begin{tabular}{|c|c|c|c|c|c|c|c|c|c|c|c|}
\hline 4492 & 0.9901 & 6 & 19.89 & 0.00223 & 0.036 & 2 & 6 & 2 Longleaf pine & 11 & 60 & 39.59 \\
\hline 4493 & 0.3668 & 30.5 & 72.67 & 0.00193 & 0.031 & 2 & 3 & 2 Longleaf pine & 64 & 60 & 56.06 \\
\hline 4494 & 0.9138 & 44 & 85.00 & 0.00359 & 0.058 & 2 & 4 & 1 Loblolly pine & 42 & 90 & 144.14 \\
\hline 4496 & 0.4209 & 40 & 71.71 & 0.00208 & 0.033 & 5 & 2 & 2 Longleaf pine & 40 & 80 & 52.50 \\
\hline 4497 & 0.8075 & 53 & 89.36 & 0.00226 & 0.036 & 4 & 0.5 & 1 Loblolly pine & 47 & 90 & 118.24 \\
\hline 4498 & 0.4845 & 22 & 43.33 & 0.00248 & 0.040 & 3 & 5 & 1 Loblolly pine & 24 & 60 & 47.75 \\
\hline 4499 & 0.6290 & 47 & 97.55 & 0.00189 & 0.030 & 3 & 1 & 1 Loblolly pine & 46 & 90 & 141.20 \\
\hline 4500 & 0.6143 & 33 & 73.30 & 0.00226 & 0.036 & 4 & 2 & 2 Longleaf pine & 42 & 80 & 75.00 \\
\hline 4501 & 0.9288 & 12 & 33.20 & 0.00718 & 0.115 & 1 & 3 & 1 Loblolly pine & 13 & 70 & 114.74 \\
\hline 4502 & 0.8385 & 47 & 92.27 & 0.00413 & 0.066 & 0 & 33 & 6 Hardwoods & 66 & 90 & 238.66 \\
\hline 4503 & 0.8938 & 14 & 35.00 & 0.00410 & 0.066 & 2 & 6 & 1 Loblolly pine & 15 & 80 & 69.44 \\
\hline 4504 & 0.8927 & 35 & 63.46 & 0.00404 & 0.065 & 0 & 33 & 1 Loblolly pine & 22 & 80 & 124.34 \\
\hline 4505 & 0.8167 & 60 & 93.79 & 0.00724 & 0.116 & 1 & 8 & 3 Slash pine & 62 & 90 & 169.63 \\
\hline 4506 & 0.9007 & 23 & 42.80 & 0.00670 & 0.107 & 4 & 0.5 & 1 Loblolly pine & 20 & 70 & 128.42 \\
\hline 4508 & 0.9330 & 18 & 39.40 & 0.00412 & 0.066 & 3 & 0.5 & 1 Loblolly pine & 14 & 70 & 71.24 \\
\hline 4510 & 0.6757 & 28 & 79.60 & 0.00153 & 0.025 & 1 & 20 & 6 Hardwoods & 58 & 80 & 139.65 \\
\hline
\end{tabular}

